\title{
Sexually Dimorphic Vasopressin Cells Modulate Social Investigation and Communication in Sex-Specific Ways
}

\author{
Nicole Rigney, ${ }^{1}$ Jack Whylings, ${ }^{1}{ }^{-}$Michihiro Mieda, ${ }^{2}$ Geert J. de Vries, ${ }^{1}$ and Aras Petrulis ${ }^{1}$
}

https://doi.org/10.1523/ENEURO.0415-18.2019

${ }^{1}$ Georgia State University, Atlanta, GA 30303, and ${ }^{2}$ Kanazawa University, Kanazawa, Ishikawa, Japan 920-1192

\begin{abstract}
The neuropeptide arginine vasopressin (AVP) has long been implicated in the regulation of social behavior and communication, but precisely which AVP cell groups are involved is largely unknown. To address whether the sexually dimorphic AVP cell group in the bed nucleus of the stria terminalis (BNST) is important for social communication, we deleted BNST AVP cells by viral delivery of a Cre-dependent caspase-3 cell-death construct in AVP-iCre-positive mice using AVP-iCre negative littermate as controls, and assessed social, sexual, aggressive and anxiety-related behaviors. In males, lesioning BNST AVP cells reduced social investigation of other males and increased urine marking (UM) in the presence of a live female, without altering ultrasonic vocalizations (USVs), resident-intruder aggression, copulatory behavior, anxiety, or investigation of females or their odor cues. In females, which have significantly fewer AVP cells in the BNST, these injections influenced copulatory behavior but otherwise had minimal effects on social behavior and communication, indicating that these cells contribute to sex differences in social behavioral function.
\end{abstract}

Key words: bed nucleus of the stria terminalis; mice; sex differences; social behavior; social communication; vasopressin

\section{Significance Statement}

Despite over thirty years of indirect evidence implicating sexually-dimorphic arginine vasopressin (AVP) cells within the bed nucleus of the stria terminalis (BNST) in the control of social and anxiety-related behavior in mammals, the function of these cells has never been directly tested. Here, we show that deletion of these cells in male, but not female, mice reduce investigation of same-sex conspecifics and alter social communication without changing aggressive and anxiety-related behaviors. Although AVP cell deletion in the BNST did not alter male copulatory behavior, it impaired female sexual behavior. These results indicate that sexually-dimorphic AVP cells in the BNST drive specific aspects of sexually-differentiated social investigation, behavior, and communication.

\section{Introduction}

Social behavior and communication show profound sex differences in many species (Darwin, 1871; Bradbury and Vehrencamp, 1998), and in humans, dysfunction in social behavior and communication is prominent in chronic, debilitating, and pervasive psychopathologies (Insel, 2010)

Received October 26, 2018; accepted January 2, 2019; First published January 15, 2019.

The authors declare no competing financial interests. that show sex differences in prevalence and clinical outcome (Halladay et al., 2015), such as autism (Schultz, 2005). One reasonable hypothesis is that sex differences in the underlying neural circuitry contribute to sexually differentiated function and dysfunction in social behavior

Author contributions: A.P. and G.d.V. designed research; N.R. and J.W performed research; M.M. contributed unpublished reagents/analytic tools; N.R. also designed experiment and analyzed data; N.R., A.P., and G.d.V. wrote the paper. 
and communication. A particularly well-positioned circuit in this respect is the arginine vasopressin (AVP) innervation of the brain, which shows marked sex differences across many species, including humans (Goodson and Bass, 2001; De Vries and Panzica, 2006; de Vries, 2008). Research across taxa confirms an important role for AVP in social behavior. For example, AVP has been implicated in aggression, pair bonding, maternal behavior, and communication across vertebrates (Goodson and Bass, 2001; Albers, 2012). However, the anatomy of AVP projections suggests that AVP control of social behavior is complex and, in most cases, the anatomic substrate of AVP's control of social behavior is unclear (Kelly and Goodson, 2013a; Ludwig and Stern, 2015; Dumais and Veenema, 2016). In most animals, AVP is synthesized in several cell groups, each of which projecting to distinct brain areas (De Vries and Boyle, 1998; Rood and De Vries, 2011; Rood et al., 2013). AVP cells in the medial amygdala (MeA) and bed nucleus of the stria terminalis (BNST) contribute to the most pronounced sex differences in AVP innervation in brain (De Vries and Boyle, 1998). For example, male rats and mice have about two to three times as many AVP cells as females in these nuclei and the projections of these cells to areas such as lateral septum (LS) are denser as well (van Leeuwen et al., 1985; Rood and De Vries, 2011; Rood et al., 2013; Otero-Garcia et al., 2014).

Various studies suggest that AVP cells in the BNST and MeA modulate pro-social as well as antagonistic behaviors. In birds, for example, partial knock-down of AVP gene expression in the BNST reduces prosocial vocalizations and social interactions in birds while increasing male-male aggression (Kelly et al., 2011; Kelly and Goodson, 2013a,b). Evidence for involvement of AVP projections from the BNST and MeA in social behavior in mammals is less direct. For example, the density of AVP fibers in BNST and MeA projection areas and c-Fos activation in AVP cells in the BNST correlate negatively with aggression in male mice and rats (Compaan et al., 1993; Everts et al., 1997; Ebner et al., 2000; Beiderbeck et al., 2007; Veenema et al., 2010) but positively with prosocial behavior (Goodson et al., 2009; Ho et al., 2010). In addition, injecting specific V1a receptor agonists or boosting $\mathrm{V} 1 \mathrm{a}$ receptor expression in target areas of AVP cells in the BNST and MeA promotes affiliation in voles (Wang et al., 1994; Liu et al., 2001; Pitkow et al., 2001; Lim and Young, 2004; Lim et al., 2004) and social recognition and active social behaviors in rats (Dantzer et al., 1988; Veenema et al., 2012). In rats, where AVP release in the septum, one

This work was supported by the National Institutes of Health Grant R21 $\mathrm{MH} 111104$

Acknowledgements: We thank Carol Wilber, Leah Krevitt, Meira Robbins, Dorena Nguyen, and Sean Bevacqua for their assistance collecting behavioral data and Jonathan Boykin for programming assistance in R.

Correspondence should be addressed to Nicole Rigney at nrigney1@ student.gsu.edu.

https://doi.org/10.1523/ENEURO.0415-18.2019

Copyright (C) 2019 Rigney et al.

This is an open-access article distributed under the terms of the Creative Commons Attribution 4.0 International license, which permits unrestricted use, distribution and reproduction in any medium provided that the original work is properly attributed. of the most prominent projection areas of BNST and MeA AVP cells (De Vries and Buijs, 1983; De Vries and Panzica, 2006), correlates positively with intermale aggression in a resident-intruder test, a behavioral response could be blocked by retro-dialysis of an AVP antagonist (Veenema et al., 2010). None of these results, however, can be tied with certainty to AVP cells in the BNST and MeA, as all these areas receive AVP input from other sources as well, most importantly the PVN (Rood et al., 2013). In addition, AVP released dendritically from neurosecretory neurons in the hypothalamus may reach these areas as well (Ludwig and Stern, 2015). To directly test the hypothesis that AVP cells in the BNST modulate social behavior, we injected an adeno-associated virus (AAV) with a Cre-dependent, genetically modified executioner caspase- 3 complex (Yang et al., 2013; Unger et al., 2015) into the BNST of adult AVP-iCre+ and AVP-iCre- (Mieda et al., 2015) male and female mice, which specifically deleted AVP cells in the area, and tested the effects of these deletions on social investigation, courtship ultrasonic vocalizations (USVs; Chabout et al., 2015), and territorial urine marking (UM; Arakawa et al., 2008b), all aspects of mouse communication known to show pronounced sex differences (Crawley, 2012; Lehmann et al., 2013; Wöhr, 2014).

\section{Materials and Methods}

\section{Animals and husbandry}

All mice were maintained at $22^{\circ} \mathrm{C}$ on a $12 / 12 \mathrm{~h}$ reverse light/dark cycle with food and water available ad libitum, housed in individually ventilated cages (Animal Care Systems), and provided with corncob bedding, a nestlet square, and a housing tube. All animal procedures were performed in accordance with the Georgia State University animal care committee regulations and the National Institutes of Health Guide for the Care and Use of Laboratory Animals.

\section{Subjects}

Founding AVP-iCre mice were obtained from Dr. Michihiro Mieda (Kanazawa University, Japan). These mice were generated using a bacterial artificial chromosome (BAC) that expressed codon-improved Cre recombinase (Shimshek et al., 2002) under the transcriptional control of the AVP promoter (AVP-iCre mice). In these animals, iCre expression is found in the BNST and the MeA, as well as in hypothalamic areas (Mieda et al., 2015). Subjects were derived by crossing heterozygous iCre+ mutants to wildtype C57BI/6J mice and genotyped (ear punch) by polymerase chain reaction (PCR) at 21-24 $d$ of age (Transnetyx). Both iCre+ and iCre- littermates were used in behavioral experiments. All subject mice were singlyhoused for a minimum of one week.

\section{Stimulus animals}

CD1(ICR) (Charles River Laboratories) mice were used as stimuli for behavioral testing and to provide male and female subjects with social experience because strain differences between subjects and stimulus mice increase social investigation (Gheusi et al., 1994). Mice were used at $9-16$ weeks of age and were novel and unrelated to the subject to which they were exposed. 
Female stimulus mice were group-housed, ovariectomized, and implanted with an estradiol capsule (GDX+E), and given two sexual experiences before testing. Two groups of stimulus males were used for behavioral testing. Mice that were used as subordinate mice in the home cage aggression tests and for providing aggressive experience to subjects, were group housed, gonadectomized (GDX), and subjected to two aggressive encounters with a dominant male. Mice in the second group, which provided sexual experience to female subjects and served as sexual partners during copulatory tests and as stimulus animal in the three-chamber social test, were singly-housed, GDX, and implanted with testosterone $(G D X+T)$, and given two sexual experiences before testing.

\section{Viral vector}

AVP driven-, Cre-expressing-BNST neurons were ablated using an AAV (AAV-flex-taCasp3-TEVp; serotype $2 / 1 ; 3 \times 10^{12} \mathrm{IU} / \mathrm{ml}$; University of North Carolina at Chapel Hill Vector Core) that encodes, in a Cre-dependent fashion, a mutated pro-caspase- 3 and its activator (TEVp; Fig. $1 A)$. This system activates an apoptotic signaling cascade, cleaving multiple structural and regulatory proteins critical for cell survival and maintenance (Yang et al., 2013) and thereby inducing far less inflammation than other lesion approaches (Morgan et al., 2014).

\section{Surgery}

All surgeries were conducted using $1.5-3 \%$ isoflurane gas anesthesia in $100 \%$ oxygen; $3 \mathrm{mg} / \mathrm{kg}$ of carprofen was given before surgery to reduce pain.

\section{Stereotaxic surgery}

Mice were positioned in a stereotaxic frame (David Kopf Instruments) with ear and incisor bars holding bregma and lambda level. After a midline scalp incision, a hand operated drill was used to make holes in the skull exposing the dura. For all subjects, $500 \mathrm{nl}$ of AAV-flex-taCasp3-TEVp was delivered bilaterally to the BNST (coordinates: AP $-0.01 \mathrm{~mm}$; ML $\pm 0.75 \mathrm{~mm}$; DV $4.8 \mathrm{~mm}$; Paxinos and Franklin, 2012) at a rate of $100 \mathrm{nl} / \mathrm{min}$ using a $5-\mu \mathrm{l} \mathrm{Ham}-$ ilton syringe with a 30-gauge beveled needle mounted on a stereotaxic injector. Following virus delivery, the syringe was left in place for $15 \mathrm{~min}$ and slowly withdrawn from the brain.

\section{Gonadectomy and hormone treatment}

Testes were cauterized and removed at the ductus deferens via a midline abdominal incision. SILASTIC capsules $(1.5-\mathrm{cm}$ active length; $1.02-\mathrm{mm}$ inner diameter, 2.16-mm outer diameter; Dow Corning Corporation) were filled with crystalline T (Sigma) and inserted subcutaneously between the scapulae after gonadectomy; this procedure leads to physiologic levels of $\mathrm{T}$ (Barkley and Goldman, 1977; Matochik et al., 1994). To further reduce aggression in stimulus animals (Beeman, 1947), some males were GDX, but did not receive a $T$ implant (GDX).

The ovaries of stimulus female mice were removed by cauterization at the uterine horn and attendant blood vessels. SILASTIC capsules $(0.7-\mathrm{cm}$ active length; 1.02-mm inner diameter, 2.16-mm outer diameter; Dow Corning Corporation) containing estradiol benzoate $(E$; diluted 1:1 with cholesterol) were implanted subcutaneously in the scapular region immediately following ovariectomy (GDX+E; Bakker et al., 2002; Ström et al., 2012). To induce sexual receptivity, stimulus females were injected subcutaneously with $0.1 \mathrm{ml}$ of progesterone $(500$ $\mu \mathrm{g}$ dissolved in sesame oil, Sigma) $4 \mathrm{~h}$ preceding sexual experience, urine collection, and behavioral testing (Veyrac et al., 2011).

\section{Social experience}

As opposite-sex sexual experience and attaining competitive status ("social dominance") promote male and female communicative behaviors (Lumley et al., 1999; Roullet et al., 2011), mice received social experience over five consecutive days (sexual encounters on days 1 and 4 , aggressive encounters on days 2 and 5 , and no encounters on day 3$)$.

\section{Sexual experience}

Subjects were given two opportunities to interact with either a stimulus female (for male subjects) or a stimulus male (for female subjects). A sexually-experienced stimulus mouse was placed in the subject's home cage and removed $5 \mathrm{~min}$ after one ejaculation or $90 \mathrm{~min}$ in the absence of ejaculation. Subjects that did not show ejaculation (two iCre- males) or did not elicit ejaculation (one iCre + female) on either trial were removed from further testing.

\section{Aggressive experience}

Male subjects were exposed to two interactions with subordinate males treated with $40 \mu \mathrm{l}$ of GDX+T male urine applied to their backs. Gonadectomy, group housing, and social defeat of our subordinates reduce offensive aggression in mice, while $\mathrm{GDX}+\mathrm{T}$ male urine provides subjects with a male urinary cue that elicits offensive aggression (Beeman, 1947; Connor and Winston, 1972; Van Loo et al., 2001). Subordinate stimulus males were placed in the subject's home cage and removed after the subject's first offensive attack (biting) within a 10-min period. All subject males attacked the intruder male stimulus by the second encounter, and all subordinate stimulus males displayed submissive behavior, defined as defensive postures (e.g., on-back), fleeing, and non-social exploring (Koolhaas et al., 2013). Female subjects were exposed to a female intruder; however, this did not elicit any attacks from either animal.

\section{Experimental procedure}

All testing occurred within the first $6 \mathrm{~h}$ of the dark cycle under red light illumination, with the exception of the elevated plus maze (EPM). All tests were scored by an experimenter blind to the genotype of the subject. Three to four weeks after viral injections, subjects were habituated to the testing room and apparatus by handling and placing mice (for $5 \mathrm{~min}$ ) in the three-chamber apparatus (see below) each day for $3 \mathrm{~d}$. On experimental days, subjects were adapted to the experimental room for 15 min before testing. First, we tested mice on an EPM to test for anxiety-related behavior (Lister, 1987). Mice were then tested in the three-chamber apparatus over six con- 
A
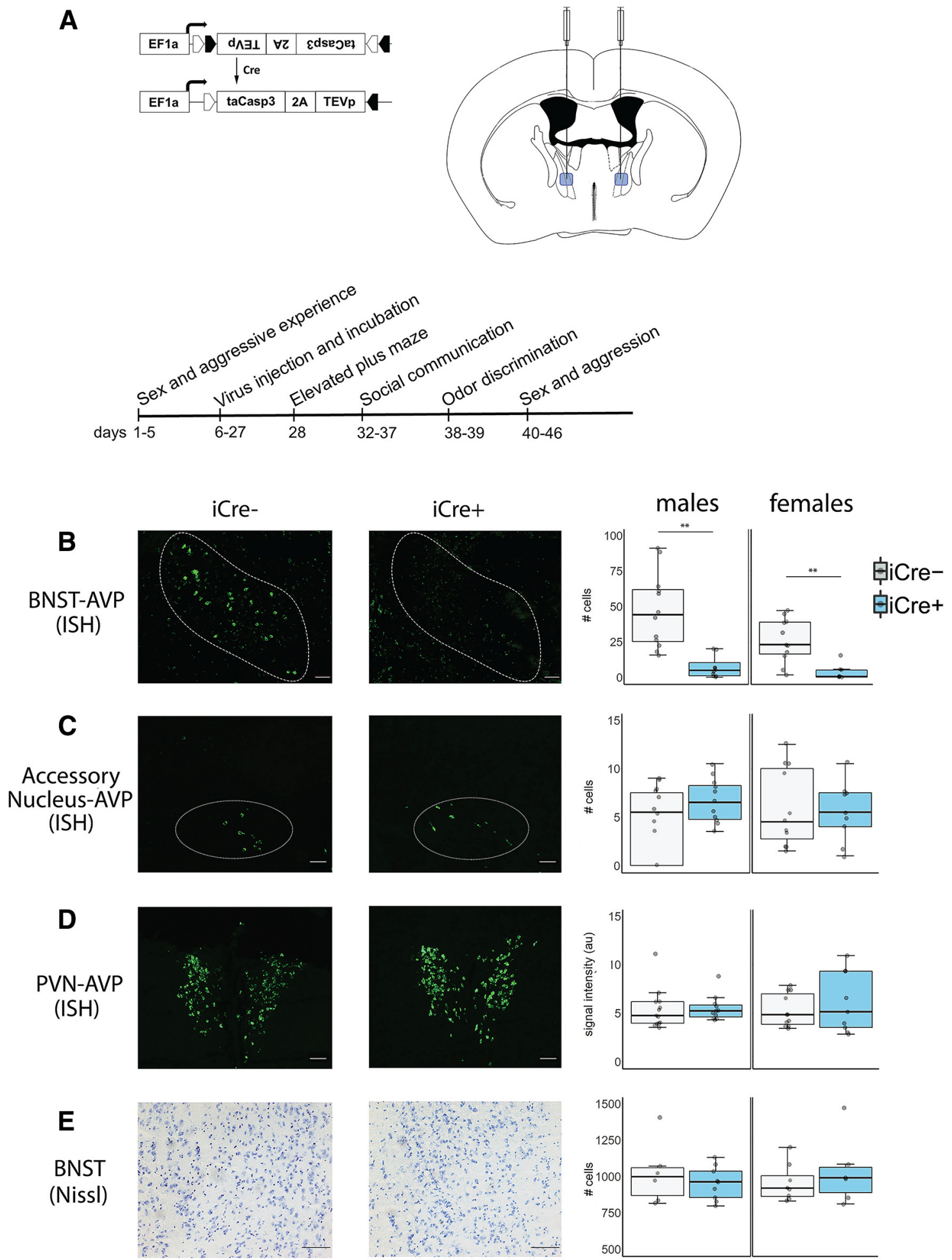

Figure 1. AVP histology and experiment timeline. A, Cre-dependent AAV (AAV-flex-taCasp3-TEVp) and location of bilateral BNST injection site; coordinates: AP $-0.01 \mathrm{~mm}$; ML $\pm 0.75 \mathrm{~mm}$; DV $4.8 \mathrm{~mm}$; modified from Paxinos and Franklin (2012). Timeline of experimental manipulations. $\boldsymbol{B}$, Example images of fluorescent in situ hybridization (ISH)-labeled BNST AVP cells and boxplot of cell number. Within the BNST, a significant decrease in AVP cell label was observed in both iCre + male and female mice compared to iCre-control animals (males: $p=0.00014$; females: $p=0.0025)$. iCre- $(n=13)$ and iCre $+(n=11)$ males and iCre- $(n=13)$ and iCre + $(n=8)$ females. $\boldsymbol{C}$, Example images of fluorescent ISH-labeled accessory nucleus-AVP cells and boxplot of cell number. No significant AVP cell loss was observed between iCre + and iCre- subjects (males: $p=0.98$; females: $p=0.89)$. iCre- $(n=13)$ and iCre $+(n=$ 11) males and iCre- $(n=13)$ and iCre $+(n=8)$ females. $\boldsymbol{D}$, Example images of fluorescent ISH-labeled PVN and boxplot of image intensity (arbitrary units). iCre+ and iCre- subjects did not differ in PVN signal intensity (males: $t_{(20)}=0.66, p=0.947$; females: $p=$ 
continued

0.29). iCre- $(n=13)$ and iCre+ $(n=10)$ males and iCre- $(n=13)$ and iCre $+(n=8)$ females. $\boldsymbol{E}$, Example images of Nissl-stained BNST tissue and boxplot of cell number. No difference in BNST cell number between iCre + and iCre- subjects was observed (males: $p=$ 0.439; females: $p=0.44)$. iCre- $(n=6)$ and iCre $+(n=9)$ males and iCre $-(n=8)$ and iCre $+(n=6)$ females. In boxplots, dots indicate individual data points, bold horizontal lines illustrate the median, the areas above and below the lines show the 1st/3rd quartile. The vertical bars range from the minimal to the maximal values excluding outliers ( \pm 1.35 SDs from interquartile range). Images were taken at $10 \times$ for fluorescent material and $20 \times$ for Nissl-stained tissue. Scale bar $=50 \mu \mathrm{m} ; * *$ indicates significant effect of genotype, $p<$ 0.005 .

secutive days with a day off on the fourth day. Lastly, odor discrimination, copulatory, and aggressive behavior were measured in the subject's home cage (Fig. 1A). Female subjects were tested irrespective of estrous cycle day, except during copulation testing, when they were in behavioral estrus. Prior research indicates minimal effects of estrous cycle on female mouse communicative behavior (Maggio and Whitney, 1985; Coquelin, 1992; MonchoBogani et al., 2004). Following testing, subjects were killed and their brain tissue was processed for in situ hybridization to detect AVP expression in BNST and nearby hypothalamic areas.

\section{Social behavior}

USV, UM, and social investigation were recorded in an acrylic three-chamber apparatus (Crawley, 2007; Arakawa et al., 2008a; Moy et al., 2009; Harvard Apparatus; dimensions: $20.3 \times 42 \times 22 \mathrm{~cm}$ ). Instead of a solid floor, the apparatus was placed on absorbent paper (Nalgene Versi-dry paper, Thermo Fisher Scientific) so as to accurately measure UM. Animals were also tracked using motion detection software (ANY-maze, San Diego Instruments, RRID:SCR_014289). During testing with stimulus animals, subjects had access to either a stimulus animal in a cage $[8 \mathrm{~cm}(\mathrm{D}), 18 \mathrm{~cm}(\mathrm{H}) ; 3-\mathrm{mm}$ diameter steel bars, $7.4 \mathrm{~mm}$ spacing] or an empty cage placed at opposite corners of the outermost chambers of the apparatus. For testing with social odors, subjects had access to $50 \mu$ l of fresh urine from a stimulus animal or $50-\mu l$ saline pipetted onto a clean piece of filter paper $\left(3 \mathrm{~cm}^{2}\right)$, that was taped on the outside of cages. The location of stimulus and the "clean" cage were counterbalanced across animals. After placing the subject in the center of the middle chamber, we measured, across a 5-min trial, close investigation of clean and stimulus cages, distance traveled throughout the apparatus, time spent in the stimulus and clean cage chambers as well as USVs and UMs. After testing, the apparatus and cages were thoroughly cleaned with $70 \%$ ethanol and allowed to dry before further testing. In all cases, urine stimulus from one sex was presented first followed by a live stimulus of that same sex; this order was then repeated for the opposite sex. In this fashion, mice experienced first weak (urine) then stronger social stimuli (stimulus animal; the order of male and female stimuli presentation was counterbalanced.

\section{Investigation and USVS}

Close investigation was defined as time spent sniffing within $2 \mathrm{~cm}$ of the stimulus or clean cage; climbing on the cage was not scored as investigation. USVs were detected using a condenser microphone connected to an amplifier (UltraSoundGate CM16/CMPA, 10-200 kHz, fre- quency range) placed $4 \mathrm{~cm}$ inside the apparatus and directly above the center compartment. USVs were sampled at $200 \mathrm{kHz}$ (16-bit) with target frequency set to 70 $\mathrm{kHz}$ (UltraSoundGate $116 \mathrm{Hb}$, Avisoft Bioacoustics). Recordings were then analyzed using a MATLAB (MathWorks, RRID:SCR_001622) plug-in that automates USV analysis (Van Segbroeck et al., 2017). Using this program, sonograms were generated by calculating the power spectrum on Hamming windowed data and then transformed into compact acoustic feature representations (Gammatone Filterbank). Each 200-ms window containing the maximum USV syllable duration was then clustered, via machine learning algorithms, into USV syllable types (repertoire units) based on time-frequency USV shape. Repertoire units that appeared as background noise were discarded. We counted the number of all USV produced by each subject. USV syllable types were identified from a subset of males (iCre- $n=6$; iCre $+n=7$ ) using criterion previously described: short, composite, downward, upward, 1 frequency jump, modulated, multiple frequency jumps, u-shape, flat, chevron (Hanson and Hurley, 2012).

\section{$U M$}

Following testing, the substrate sheet was allowed to dry for $1 \mathrm{~h}$ and then sprayed with ninhydrin fixative (LCNIN-16; Tritech Forensics Inc.) to visualize urine marks (Meyer, 1957; Lehmann et al., 2013). After 24 h, sheets were imaged (Sony DSC-S700 camera), binarized and analyzed using a computer-aided imaging software (ImageJ, RRID:SCR_003070). UM was measured as the total area $\left(\mathrm{cm}^{2}\right)$ of visualized ninhydrin urine marks in the entire arena. Urine marks that were larger than $6 \mathrm{~cm}^{2}$ and directed toward corners were counted as eliminative "pools" and were counted separately (Bishop and Chevins, 1987).

\section{Copulatory and aggressive behavior}

To measure copulatory behavior, the stimulus mouse was placed in the subject's home cage and then removed 5 min after one ejaculation had occurred or if 90 min had elapsed without copulation. The latency and total time investigating the anogenital region, latency to mount, percentage of females that were mounted, percentage of male ejaculations, and number of mount rejections (female kicking male off during mounting attempt) in female subjects was recorded. To measure territorial aggression, subordinate stimulus males were placed in the subject's home cage and then removed after the subject's first offensive attack (biting) within a 10-min period; the latency to first bite was recorded. 


\section{Odor discrimination}

We used a habituation-discrimination procedure on a subset of subjects to test whether they could distinguish between social odors (Baum and Keverne, 2002). Subjects were given five consecutive 2-min presentations of an odor stimulus with one min intervals between presentations. Subjects were first presented with deionized water, followed by two non-social odors $(100 \%$ almond, lemon, or vanilla extract, Frontier Natural Products), and then two urine samples (one from each sex) within their home cage. The sequence of odor presentation was counterbalanced within non-social or social odor category. Each odor stimulus $(30 \mu \mathrm{l})$ was placed onto a clean piece of filter paper $\left(3 \mathrm{~cm}^{2}\right)$ taped to an empty food hopper such that subjects could contact the urine samples. Time spent sniffing within $2 \mathrm{~cm}$ of the filter paper was recorded. Food hoppers were cleaned with $70 \%$ ethanol and allowed to dry between each odor presentation.

\section{EPM}

The EPM consisted of two open arms $(30 \times 5 \mathrm{~cm})$ and two closed arms $(30 \times 25 \times 5 \mathrm{~cm})$ crossed perpendicularly and raised $60 \mathrm{~cm}$ above the floor. Subjects were placed at the arm intersection facing the open arm and were allowed to habituate to the apparatus for $1 \mathrm{~min}$; subjects were then observed for an additional $5 \mathrm{~min}$. Animals were tracked by ANY-maze so that measurements of time spent in open and closed arms were recorded automatically whereas the number of risk assessment behaviors (stretch-attend posture, headdips) were manually scored from video (Cole and Rodgers, 1993).

\section{Urine collection}

Pooled urine samples were collected from stimulus females induced into estrus and from stimulus males (five to eight mice per sample). Estrous state was verified by color, swelling, and expanded size of vaginal opening (Caligioni, 2009). To collect urine, mice were picked up by the tail base and held by dorsal neck skin; this method was often sufficient to induce urination. If the mouse did not urinate, stroking its belly from an anterior to posterior direction stimulated bladder voiding. Each mouse provided $15-50 \mu \mathrm{l}$ of urine that was pooled into a $1.5-\mathrm{ml}$ Eppendorf tube. Urine samples were used fresh within $1 \mathrm{~h}$ of collection to prevent chemosignal degradation (Roullet et al., 2011).

\section{Histology and in situ hybridization}

Following testing, subjects were killed via $\mathrm{CO}_{2}$ asphyxiation. Brains were extracted and flash frozen via submersion in 2-methyl-2-butanol (Sigma) for 10-20 s and stored at $-80^{\circ} \mathrm{C}$ until sectioned. Coronal sections $(20 \mu \mathrm{m})$ were cut with a cryostat (Leica CM3050 S, Leica Biosystems) into three series and stored at $-80^{\circ} \mathrm{C}$. All tissue was handled in a RNase-free environment. Tissue was postfixed in paraformaldehyde, followed by a wash in $2 \times$ saline-sodium citrate (SSC) and acetylation in a triethanolamine/acetic anhydride solution, rinsed in $\mathrm{dH}_{2} \mathrm{O}$, washed in acetone/methanol solutions (1:1), and again in
$2 \times$ SSC. Tissue was first incubated at $65^{\circ} \mathrm{C}$ in hybridization buffer $(50 \%$ deionized formamide, $1 \%$ yeast tRNA, $10 \%$ dextran sulphate, $1 \times$ Denhardt's solution, $5 \% 20 \times$ $\mathrm{SSC})$ for $30 \mathrm{~min}$ before probe application. Riboprobes were developed from linearized PK Bluescript SK(+) with inserted mouse-vasopressin gene (NM_027106.4, Genscript) using digoxygenin (DIG)-conjugated uracil. Riboprobe synthesized from this plasmid was added to hybridization buffer at a concentration of $100 \mathrm{ng} / 100 \mu \mathrm{l}$ and denatured at $90^{\circ} \mathrm{C}$ for $5 \mathrm{~min}$. Tissue was then hybridized at $65^{\circ} \mathrm{C}$ for $24 \mathrm{~h}$ in a humid chamber. The tissue was then subjected to two 10-min washes in $2 \times$ SSC at room temperature followed by a 15-min digestion with RNase A $(10 \mathrm{~g} / \mathrm{ml}$ in $2 \times \mathrm{SSC})$ at $37^{\circ} \mathrm{C}$. This was followed by a 30 -min $2 \times$ SSC wash at $56^{\circ} \mathrm{C}$ and two 10 -min $2 \times$ SSC washes at room temperature. The tissue was then quenched in $1 \% \mathrm{H}_{2} \mathrm{O}_{2}$ in $1 \times \mathrm{SSC}$ for $15 \mathrm{~min}$, rinsed twice in $1 \times$ SSC with $0.1 \%$ Tween followed by one 5 -min TBS (20 mM Tris and $150 \mathrm{mM} \mathrm{NaCl}, \mathrm{pH}$ 7.6) wash. Blocking solution (normal sheep serum and bovine caesin) was applied and tissue was incubated for 30 min followed by a 2-h, room temperature incubation with anti-DIG-HRP (1:200, Roche Applied Sciences). Unbound antibody was washed away with three 10-min washes in TBS-T $(0.05 \%$ Tween in TBS). DIG-labeled probe signal was amplified and visualized using a TSA Plus Fluorescein kit (PerkinElmer) by incubating sections in a 1:50 dilution of the Fluorescein working solution for $12 \mathrm{~min}$ followed by three 10-min washes in TBS. Tissue was then cover-slipped using Prolong Gold (Life Technologies) for subsequent imaging and tissue analysis. Tissue processed using sense RNA probe generated no specific labeling. A subset of brain sections was Nissl stained to determine whether viral vector injections resulted in a non-specific loss of BNST cells.

\section{Tissue analysis}

Bilateral images were taken at $10 \times$ magnification using a Zeiss Axio Imager.M2 microscope (Carl Zeiss Microimaging), which transferred fluorescent images (FITC contrast reflector) to image analysis software (Stereo Investigator, MicroBrightField, RRID:SCR_002526). Imaging domains $\left(2 \mathrm{~mm}^{2}\right)$ were placed with reference to anatomic landmarks (ventricles, fiber tracts; Paxinos and Franklin, 2012). Fluorescently labeled AVP mRNAexpressing cells were counted in the BNST in both hemispheres and averaged over three sections covering the extent of the AVP cell population in the BNST. In addition, we counted nearby accessory AVP mRNA expressing cells (Rood and De Vries, 2011) as well as average label intensity for AVP mRNA in the paraventricular nucleus of the hypothalamus (PVN; ImageJ) to determine any possible off-target effects of our injections. Although we counted AVP mRNA-expressing cells in the PVN as well, AVP mRNA label intensity was chosen as the preferred method for quantification due to the difficulty of discriminating between overlapping AVP cells in PVN. Lastly, we Nissl stained and imaged BNST tissue at 20× magnification to confirm no significant cell loss. 
Table 1 Statistical analysis

Figure
$1 B$, AVP cell count in
BNST
$1 C$, AVP cell count in
nearby accessory area
$1 D$, AVP fluorescent
intensity (au) in the
PVN and cell count in
the PVN

$1 E$, Nissl cell count in
BNST
$2 A, B$, social investigation
(live animal condition)

Data structure

Normal distribution

Independent samples $t$ test

Normal distribution Independent samples $t$ test

Normal distribution Independent samples $t$ test

Normal distribution Independent samples $t$ test

Normal distribution Mixed model analysis with one between-subject factor (genotype) and two repeated measure [sex of stimulus, location of stimulus (two levels)], followed by independent samples $t$ test with Bonferroni correction (urine condition)
Normal distribution Mixed model analysis with one between-subject factor (genotype) and two repeated measure [sex of stimulus, location of stimulus (two levels)]
Sample size

Males: AVP-iCre- $=13$ AVP-iCre+ $=11$

Females: AVP-iCre- $=13$ AVP-iCre $+=8$

Males: AVP-iCre- $=13$ AVP-iCre $+=11$ Females: AVP-iCre- $=13$ AVP-iCre $+=8$ Males: AVP-iCre- $=13$ AVP-iCre $+=10$ Females: AVP-iCre- $=13$ AVP-iCre $+=8$

Males: AVP-iCre- $=6$ AVP-iCre $+=9$ Females: AVP-iCre- $=8$ AVP-iCre $+=6$ Males: AVP-iCre- $=13$ AVP-iCre $+=11$ Females: AVP-iCre- $=13$ AVP-iCre $+=8$

o


Table 1 Continued

\section{Figure \\ Table 2, social \\ investigation (time spent}

in zones, live animal

condition
Table 2, socia investigation (distance traveled, live animal condition)

Not shown, social investigation (time spent in zones, urine condition)
Normal distribution Mixed model analysis with one between-subject factor (genotype) and one repeated measure (sex of stimulus)

Normal distribution Mixed model analysis with one between-subject factor (genotype) and two repeated measure [sex of stimulus, location of zone (two levels)]
Not shown, social investigation (distance traveled, urine condition)
Normal distribution

Mixed model analysis with one between-subject factor (genotype) and one repeated measure (sex of stimulus), followed by independent samples $t$ test with Bonferroni correction

$3 A, B$, UM (live animal

es: mixed model condition)

Males: normal distribution Females: non-normal

$3 C, D$, UM (urine condition) Males: norma distribution Females: non-normal
Males: AVP-iCre- $=13$ AVP-iCre $+=10$ Females: AVP-iCre- $=13$ AVP-iCre $+=8$

Males: AVP-iCre- $=13$ AVP-iCre $+=10$ Females: AVP-iCre- $=13$ AVP-iCre $+=8$

Males: AVP-iCre- $=13$ AVP-iCre $+=10$ Females: AVP-iCre- $=13$ AVP-iCre $+=8$

Males: AVP-iCre- $=13$ AVP-iCre $+=10$ Females: AVP-iCre- $=13$ AVP-iCre $+=8$ between-subject factor (genotype) and one repeated measure (sex of stimulus), followed by independent samples $t$ test with Bonferroni correction

Females: Mann-Whitney $U$ test, independent samples with Bonferroni correction

Males: mixed model analysis with one between-subject factor (genotype) and one repeated measure (sex of stimulus)

Females: Mann-Whitney $U$ test, independent samples with Bonferroni correction

Males: AVP-iCre- $=13$ AVP-iCre $+=10$ Females: AVP-iCre- $=13$ AVP-iCre $+=8$

\author{
Males: AVP-iCre- $=13$ AVP-iCre $+=10$ \\ Females: AVP-iCre- $=13$ AVP-iCre $+=8$
}

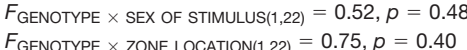

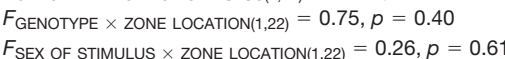

$F_{\text {GENOTYPE }} \times$ SEX OF STIMULUS $\times$ ZONE LOCATION $(1,22)=0.56$, $p=0.82$

Females:

$F_{\text {ZONE LOCATION(1,19) }}=1.14, p=0.30 F_{\text {GENOTYPE }(1,19)}=$ $4.28, p=0.54$

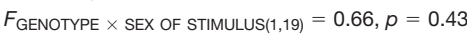

$F_{\text {GENOTYPE } \times \text { ZONE LOCATION }(1,19)}=5.10, p=0.12$

$F_{\text {SEX OF STIMULUS } \times \text { ZONE LOCATION(1,19) }}=0.19, p=0.67$

$F_{\text {GENOTYPE }} \times$ SEX OF STIMULUS $\times$ ZONE LOCATION $(1,19)=$ $0.0003, p=0.99$

Males: $F_{\text {SEX OF STIMULUS(1,22) }}=0.73, p=0.79$

$F_{\text {GENOTYPE(1,22) }}=2.85, p=0.11$

$F_{\text {GENOTYPE } \times \text { SEX OF STIMULUS(1,22) }}=0.70, p=0.41$

Females:

$F_{\text {SEX OF STIMULUS(1,19) }}=0.15, p=0.70$

$F_{\text {GENOTYPE(1,19) }}=7.6, p=0.012$

$F_{\text {GENOTYPE } \times \text { SEX OF STIMULUS }(1,19)}=0.33, p=0.57$

distance traveled in male urine condition: $p=0.05$ (two-tailed), $t=-2.42, \mathrm{df}=19$

distance traveled in male urine condition: $p=0.19$ (two-tailed), $t=-1.93, \mathrm{df}=19$

Males: $F_{\text {SEX OF StIMULUS(1,22) }}=52.62, p=0.00000029$

$F_{\text {GENOTYPE(1,22) }}=23.72, p=.000072$

$F_{\text {GENOTYPE } \times \text { SEX OF STIMULUS }(1,22)}=21.02, p=0.000145$ UM to female stimulus: $p=0.000112$ (two-tailed) $t=$ $-4.6, \mathrm{df}=22$; Cohen's $d=2.04$

UM to male stimulus: $p=0.16$ (two-tailed) $t=-1.45$, $\mathrm{df}=22$

Females:

UM to female stimulus across genotype: $p=0.15$ (two-tailed), $U=20$

UM to male stimulus across genotype: $p=0.32$ (two tailed), $U=32$

Males: $F_{\text {SEX OF STIMULUS(1,22) }}=0.53, p=0.48$

$F_{\text {GENOTYPE(1,22) }}=12.51, p=0.002$

$F_{\text {GENOTYPE } \times \text { SEX OF STIMULUS(1,22) }}=0.16, p=0.70$ Females:

UM to female stimulus across genotype: $p=0.467$ (two-tailed), $U=52$

UM to male stimulus across genotype: $p=0.858$ (twotailed), $U=32$

(Continued) 
Table 1 Continued

Figure
$4 A, B$, USVs (live anima
condition)
condition)

$4 E, F$, USVs (live animal condition), syllable type

$4 C, D$, USVs (urine condition)

$5 A, B$, EPM (open/closed arm measurements)

$5 C, D$, EPM (additiona anxiety measurements)

$6 A, B$, sex behavior (latency to mount, number of female rejections)

$6 C, D$, sex behavio (percent mounted) $7 A$, aggressive behavior (latency)

$7 B$, aggressive behavior (percent attacking) $8 A, B$, odor discrimination

Data struct
Non-normal

$$
\begin{aligned}
& \text { Mann-Whitney U test, } \\
& \text { independent samples } \\
& \text { with Bonferroni } \\
& \text { correction }
\end{aligned}
$$$$
\text { Type of test }
$$

\section{Non-normal/} homogenous

Mann-Whitney $U$ test, independent samples with Bonferroni correction

Non-normal

Mann-Whitney $U$ test, independent samples with Bonferroni correction

Normal distribution

Mixed model analysis with one between-subject factor (genotype) and one repeated measure (open/closed arm)

Normal distribution Mixed model analysis with one between-subject factor (genotype) and one repeated measure (stretch attends/head dips)

Normal distribution Independent samples $t$ test with Bonferroni correction

NA

Pearson's $\chi^{2}$

Non-normal

Mann-Whitney $U$ test, independent samples

NA

Pearson's $\chi^{2}$

Normal distribution

\section{Sample size}

Females: AVP-iCre- $=13$ AVP-iCre $+=8$

Males: AVP-iCre- $=6$ AVP-iCre $+=7$

Males: AVP-iCre- $=13$ AVP-iCre $+=10$ Females: AVP-iCre- $=13$ AVP-iCre $+=8$

Males: AVP-iCre- $=13$ AVP-iCre $+=10$ Females: AVP-iCre- $=13$ AVP-iCre $+=8$

Males: AVP-iCre- $=13$ AVP-iCre $+=10$ Females: AVP-iCre- $=13$ AVP-iCre $+=8$ Females: AVP-iCre- $=13$ AVP-iCre $+=8$

Males: AVP-iCre- $=13$ AVP-iCre $+=10$ Females: AVP-iCre- $=13$ AVP-iCre $+=8$ Males: AVP-iCre- $=13$ AVP-iCre $+=10$ Females: AVP-iCre- $=13$ AVP-iCre $+=8$

Males: AVP-iCre- $=13$ AVP-iCre $+=10$ Females: AVP-iCre- $=13$ AVP-iCre $+=8$ Males: AVP-iCre- $=11$ AVP-iCre $+=5$ Females: AVP-iCre- $=5$ AVP-iCre $+=7$
Males: AVP-iCre- $=13$ AVP-iCre $+=10$

Males: AVP-iCre- $=13$ AVP-iCre $+=10$

Statistical data

Males: USV to female stimulus across genotype: $p=$ 1.0 (two sided), $U=64$

USV to male stimulus across genotype: $p=0.334$ (two sided), $U=47$

Females: USV with male stimulus across genotype: $p$ $=0.16$ (two-tailed), $U=52$

USV to female stimulus across genotype: $p=0.18$ (two-tailed), $U=58$

Males: USV syllable type (all two-tailed):

short: $p=0.14, U=10$, composite: $p=1.0, U=22$, downward: $p=0.63, U=17$,

upward: $p=0.63, U=17,1$ frequency jump: $p=$ $0.45, U=15$, modulated: $p=0.37, U=27$, multiple frequency jumps: $p=0.63, U=24.5$, ushape: $p=0.83, U=19.5$, flat: $p=0.73, U=18$, chevron: $p=0.08, U=39$

Males: USV to female stimulus across genotype: $p=$ 0.77 (two sided), $U=60$

USV to male stimulus across genotype: $p=0.50$ (two sided), $U=52$

Females: USV with male stimulus across genotype: $p$ $=0.49$ (two sided), $U=58$

USV to female stimulus across genotype: $p=0.26$ (two sided), $U=60$

Males: $F_{\text {OPEN/CLOSED ARM(1,22) }}=51.74, p=7.826 \mathrm{E}-7$

$F_{\text {GENOTYPE(1,22) }}=0.36, p=0.52$

$F_{\text {GENOTYPE } \times \text { OPEN/CLOSED ARM }(1,22)}=2.81, p=0.11$

Females: $F_{\text {OPEN/CLOSED ARM(1,19) }}=189.41, p=$ 2.477E-11

$F_{\mathrm{GENOTYPE}(1,19)}=0.30, p=0.60$

$F_{\text {GENOTYPE }} \times$ OPEN/CLOSED ARM(1,19) $=1.30, p=0.59$

Males: $F_{\text {STRETCH ATTENDS/HEAD DIPS(1,22) }}=262.1, p=$ $1.0479 \mathrm{E}-13$

$F_{\text {GENOTYPE }(1,22)}=0.68, p=.42$

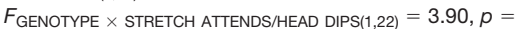
0.16

Females: $F_{\text {STRETCH ATTENDS/HEAD DIPS(1,19) }}=33.82, p=$ 0.000016

$F_{\text {GENOTYPE }(1,19)}=2.03, p=0.17$

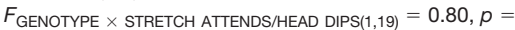
0.382

Males: latency to mount: $p=0.31$ (two-tailed), $t=$ $1.04, \mathrm{df}=22$

Females: latency to be mounted: $p=0.03$ (two-tailed), $t=-0.52, \mathrm{df}=19$

number of rejections: $p=0.61$ (two-tailed), $t=-0.52$, $\mathrm{df}=19$

Males: Pearson's $\chi^{2}: p=0.34$

Females: Pearson's $\chi^{2}: p=1.2797 \mathrm{E}-27$

Males: latency to attack across genotype: $p=0.955$ (two sided), $U=60$

Females: NA

Males: Pearson's $\chi^{2}: p=0.85$ (two sided)

Females: NA

Males (all two-tailed, iCre- $\mathrm{df}=10$, iCre $+\mathrm{df}=4$ ):

water (3) vs almond (1): $t=5.132, p=0.0004$ (iCre-), $t_{(4)}=5.261, p=0.006$ (iCre + )

Bonferroni correction between odors almond (3) vs coconut (1): $t=1.21, p=0.20$ (iCre-), $t=1.725, p=0.16$ (iCre + )

coconut (3) vs male urine (1): $t=11.41, p<0.00001$ (iCre-), $t=6.675, p=0.003$ (iCre+)

male urine (3) vs female urine (1): $t=7.936, p=$ 0.00001 (iCre-), $t=8.313, p=0.001$ (iCre + )

Females (all two-tailed, iCre- $\mathrm{df}=10$, iCre $+\mathrm{df}=4$ ): water (3) vs almond (1): $t=1.431, p=0.226$ (iCre-), $t=1.56, p=0.218$ (iCre + )

almond (3) vs coconut (1): $t=2.250, p=0.09$ (iCre-) $t=2.10, p=0.10(\mathrm{iCre}+)$

coconut (3) vs male urine (1): $t=6.197, p=0.003$ (iCre-), $t=7.454, p=0.0003$ (iCre+)

male urine (3) vs female urine (1): $t=7.071, p=0.002$ (iCre-), $t=5.211, p=0.002$ (iCre + ) 
Stimulus: Animal
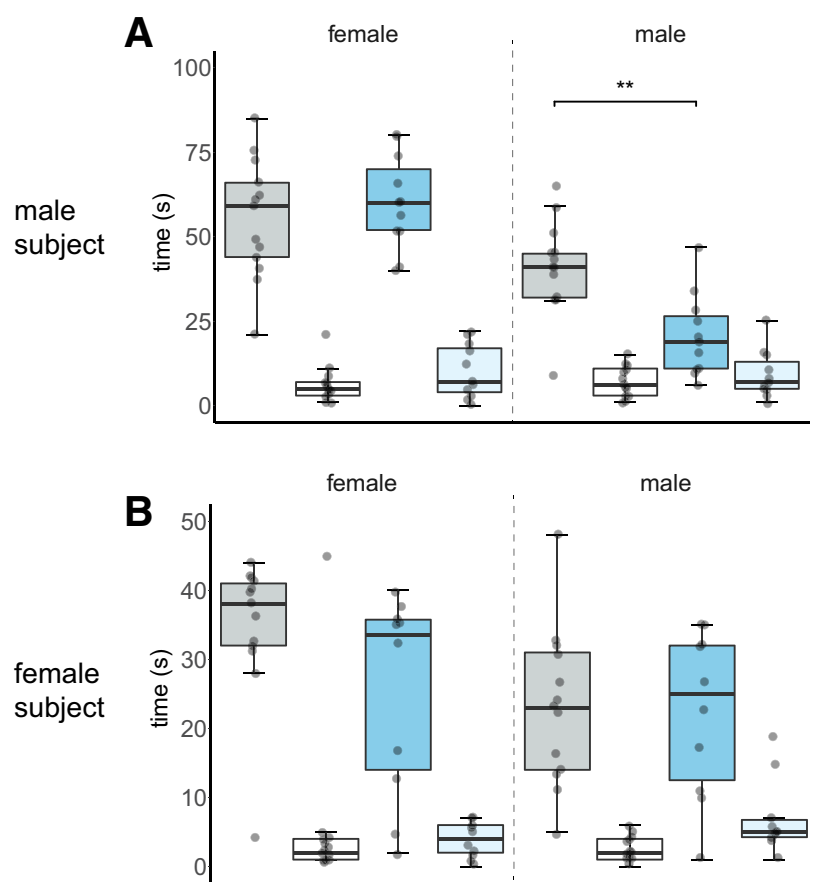

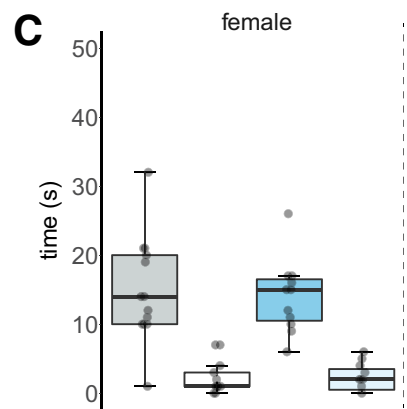

Stimulus: Urine

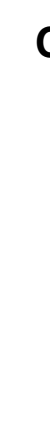

D

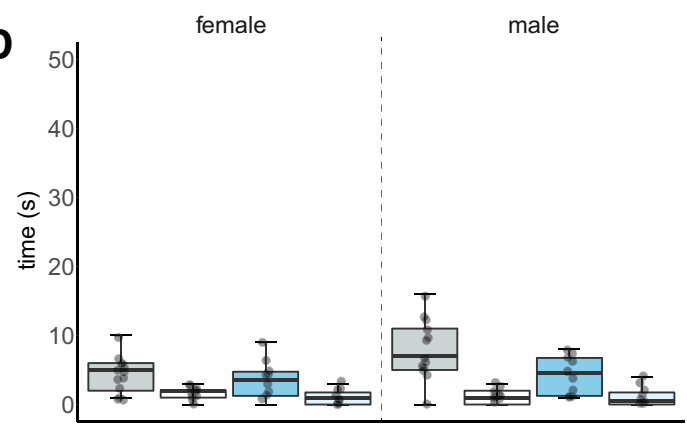

白iCre- stimulus icicre-clean Giicre+ stimulus Biicre+ clean

Figure 2. BNST AVP cell ablations in iCre+ males reduced male-male social investigation. Boxplot and individual data points of time spent investigating male or female animals or their urine versus clean control stimuli within the three-chamber apparatus. $\boldsymbol{A}$, $\boldsymbol{B}$, Time spent investigating either a caged female versus a clean cage or a caged male versus clean cage. $\boldsymbol{A}$, iCre- (males: $n=13$, females: $n=13)$ and iCre+ mice (males: $n=11$, females: $n=8$ ) differed in preference for investigating the stimulus depending on the sex of stimulus $(p=0.003)$. Post hoc analysis revealed iCre+ males significantly decreased investigation of the male animal compared to iCre- littermates $p=0.004$. $\boldsymbol{B}$, iCre- and iCre+ females did not differ in investigation $(\boldsymbol{p}=0.94)$. $\boldsymbol{C}, \boldsymbol{D}$, Time spent investigating either female urine or male urine versus saline control placed on filter paper. iCre- and iCre+ subjects did not differ in their investigation of female or male urine. $\boldsymbol{C}$, Male subjects: $p=0.64$. $\boldsymbol{D}$, Female subjects: $p=0.10$. Note scale difference in animal investigation time between male and female subjects; $* *$ indicates significant effect of genotype, $p=0.004$. Boxplot representations as in Figure 1.

\section{Statistical analysis}

All data were analyzed and graphed in $\mathrm{R}$ (3.4.4; $\mathrm{R}$ Core Team, 2017). Histology, social investigation, movement, UM (in male subjects), odor discrimination, and EPM data met the assumptions of parametric statistical tests. Therefore, we analyzed histologic data with $t$ tests and data on social investigation, movement (distance traveled, time in chambers containing stimulus and clean cages) and male UM with mixed-model ANOVAs [betweensubject factor: genotype (iCre+, iCre-); within-subject factors: sex of stimulus (male, female); preference for stimulus (stimulus, clean) followed by $t$ tests assessing genotype effects]. Total distance traveled within the apparatus was analyzed using a mixed-model ANOVA (between-subject factor: genotype; within-subject factor: sex of stimulus) as was time spent in open/closed arms in the EPM test (between-subject factor: genotype; withinsubject factor: arm); effects of genotype on additional anxiety behaviors (stretch-attend, head-dips) were analyzed using $t$ tests. We determined whether subjects could discriminate between odors by comparing odor investigation on the last trial for one odor and odor investigation on the first trial of the subsequent odor using paired $t$ tests. The number of female UMs, USVs, USV syllable type, measures of copulatory behavior, and aggression behavior were not normally distributed and could not be transformed, therefore, we analyzed genotype effects using pairwise Mann-Whitney $U$ tests. Differences in proportion of animals engaging in copulatory/aggressive behaviors across genotype was assessed using $\chi^{2}$ tests. All post hoc pairwise comparisons report Bonferroni-corrected $p$ values and Cohen's $d$ for effect size when statistically significant. Results were considered significant if $p<0.05$. All statistical tests are presented in Table 1.

\section{Results}

\section{Histology}

Injection of a viral vector encoding a Cre-dependent cell-death construct into the BNST highly effectively reduced AVP cell numbers in both iCre+ males and females, which had only $10 \%$ of the number found in iCresubjects (males: $t_{(22)}=4.57, p=0.00014, d=2.64$; females: $t_{(19)}=3.58, p=0.0025, d=2.02$; Fig. $1 B$ ), without significantly reducing the number of nearby accessory AVP mRNA-expressing cells (males: $t_{(22)}=-0.16$, $p=0.98$; females: $t_{(19)}=-0.15, p=0.89$; Fig. $1 C$ ) or total level of AVP mRNA label in the PVN (males: $t_{(20)}=0.66, p$ $=0.947$; females: $t_{(19)}=-1.10, p=0.29$; Fig. $1 D$ ), suggesting that there were no significant off-target effects. We also observed no difference in the number of AVP mRNA-expressing cells in the PVN between genotype 
Table 2. Table of median (interquartile range) distance traveled and time spent in stimulus or clean cage chamber

\begin{tabular}{|c|c|c|c|c|c|c|c|c|}
\hline & Male subjects & & & & Female subjects & & & \\
\hline iCre- & & iCre+ & & iCre- & & iCre+ & & \\
\hline Stimulus & Female & Male & Female & Male & Female & Male & Female & Male \\
\hline Distance traveled $(\mathrm{m})$ & $0.33(0.22-0.54)$ & $0.32(0.16-0.5)$ & $0.34(0.19-0.48)$ & $0.29(0.13-0.44)$ & $0.28(0.08-0.38)$ & $0.23(0.01-0.47)$ & $0.35(0.16-0.42)$ & $0.34(0.04-0.5)$ \\
\hline Time in stimulus chamber (s) & $185(129-248)$ & $127(78-195)$ & $175(111-229)$ & $97(15-209)$ & $174(102-246)$ & $147(30-227)$ & $155.75(23-198)$ & $119(91-155)$ \\
\hline Time in clean chamber (s) & $86(45-122)$ & $127(73-155)$ & $90(49-158)$ & $130(67-231)$ & $90(43-176)$ & $113(52-240)$ & $106(48-170)$ & $136(74-282)$ \\
\hline
\end{tabular}

iCre- and iCre + mice did not differ in distance traveled, time spent in animal stimulus, or clean stimulus chambers.

(males: $t_{(20)}=0.66, p=0.514$; females: $t_{(19)}=0.79, p=$ 0.82; Table 1). In addition, Nissl-stained tissue from a subset of subjects revealed no overall cell loss in the BNST (males: $t_{(13)}=0.79, p=0.439$; females: $t_{(12)}=$ $-0.80, p=0.44$ (Fig. 1E). Two iCre+ males and two iCre+ females were removed from the analysis as their AVP cell numbers in the BNST were $>3$ standard deviations above the mean, which we interpreted as off-target injections. Two additional iCre + females were removed due to unilateral AVP cell loss in the PVN.

\section{BNST AVP cell ablations in iCre+ males reduced male-male social investigation}

Mice from both genotypes investigated female stimulus animals more than male stimulus animals (males subjects: $F_{(1,22)}=261.34, p<0.00001$; female subjects: $F_{(1,19)}=$

A

Stimulus: Animal

female

male

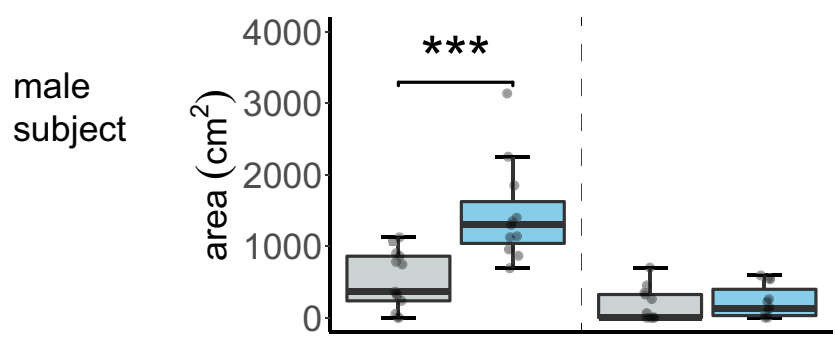

B

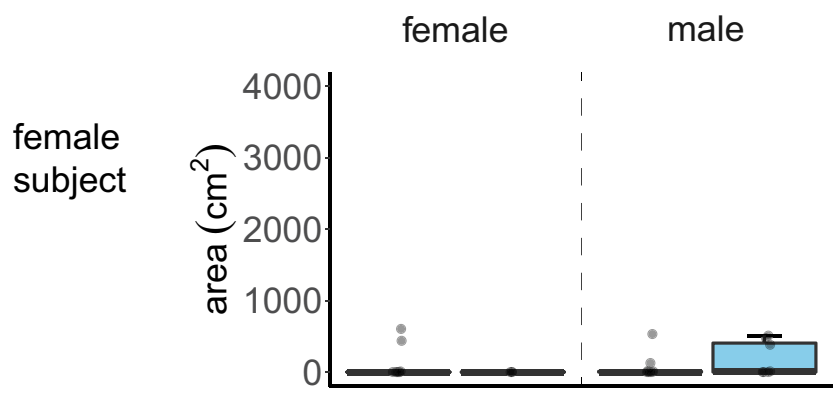

55.92, $p<0.00001)$ and had similar overall levels of investigation (male subjects: $F_{(1,22)}=0.62, p=0.438$; female subjects: $\left.F_{(1,19)}=1.60, p=0.29\right)$. However, iCreand iCre+ males differed in preference for investigating the stimulus animal depending on the sex of stimulus $\left(F_{(1,22)}=11.16, p=0.003\right)$. Post hoc comparisons revealed that iCre+ males significantly decreased investigation of male animals compared to iCre- littermates $\left(t_{(22)}\right.$ $=3.75, p=0.004, d=1.52$; Fig. $2 A$ ) but not female stimulus animals $\left(t_{(22)}=-0.70, p=1.0\right)$, while ablation of these cells in females did not affect social investigation $\left(F_{(1,19)}=0.004, p=0.94\right.$; Fig. $\left.2 B\right)$.

Males of both genotypes investigated female urine more than male urine $\left(F_{(1,22)}=117.39, p<0.00001\right)$, whereas female subjects investigated male urine more than female urine $\left(F_{(1,19)}\right.$ $=60.33, p<0.00001)$. iCre + mice did not investigate urine
Stimulus: Urine

female male

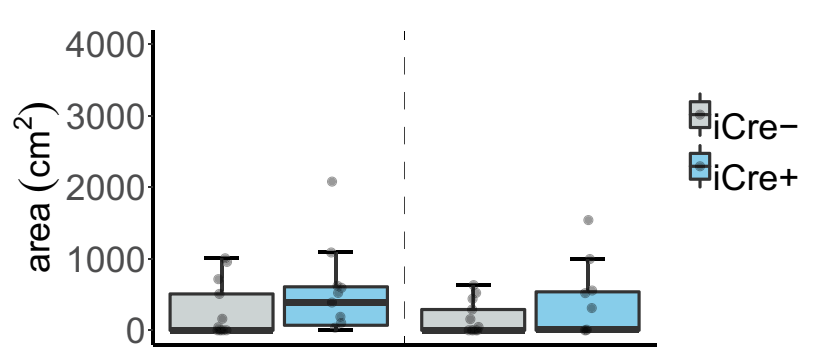

D

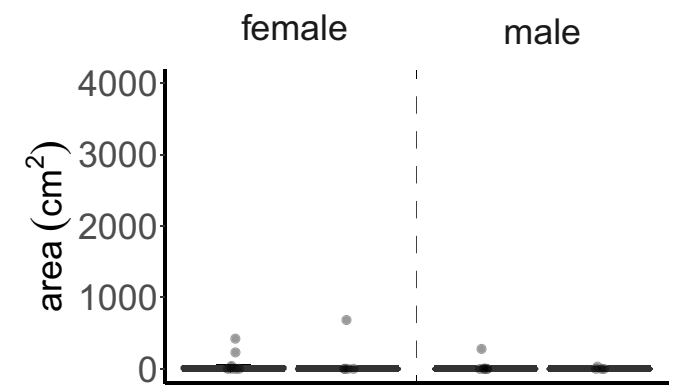

Figure 3. BNST AVP cell ablations in iCre+ males increased UM to females. Boxplot and individual data points of UM in presence of males or females or their urine within the three-chamber apparatus. $\boldsymbol{A}$, iCre- (males: $n=13$, females: $n=13$ ) and iCre+ mice (males: $n=11$, females: $n=8$ ) differed in UM depending on the sex of stimulus $(p=0.00015)$. Post hoc analysis revealed iCre + males significantly increased UM to the female stimulus compared to iCre- littermates $(p=0.000112)$. $\boldsymbol{B}$, iCre- and iCre+ females did not differ in UM to stimulus animals $[p=0.32$ (males), $p=0.15$ (females)]. $\boldsymbol{C}, \boldsymbol{D}$, UM with either female urine or male urine present. iCreand iCre+ subjects did not differ in UM to female or male urine. $\boldsymbol{C}$, Male subjects: $p=0.70$. $\boldsymbol{D}$, Female subjects: $p=0.467$ (female stimulus), $p=0.858$ (male stimulus); $* * *$ indicates significant effect of genotype, $p=0.00015$. Boxplot representations as in Figure 1. 
C Stimulus: Urine
A Stimulus: Animal

B

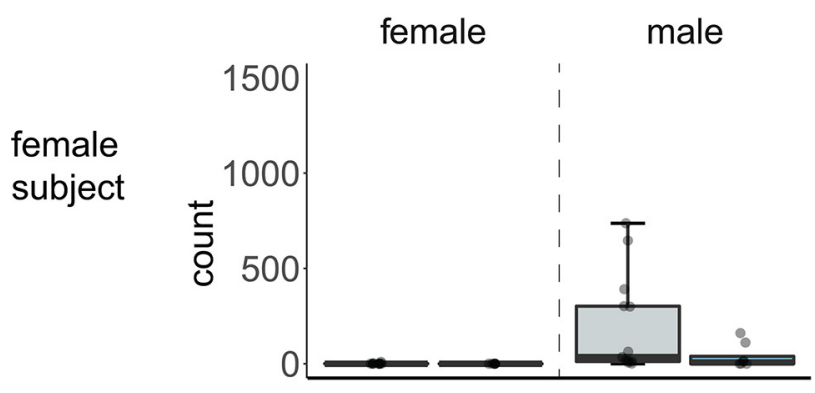

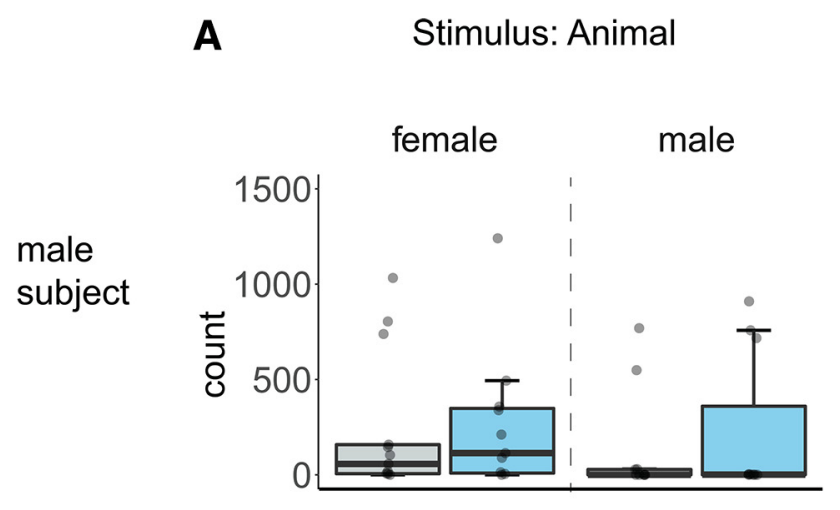

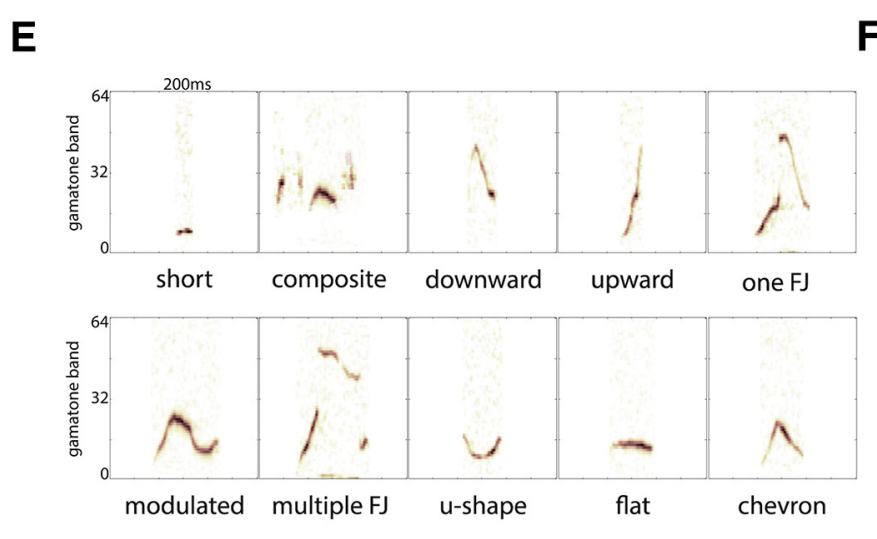

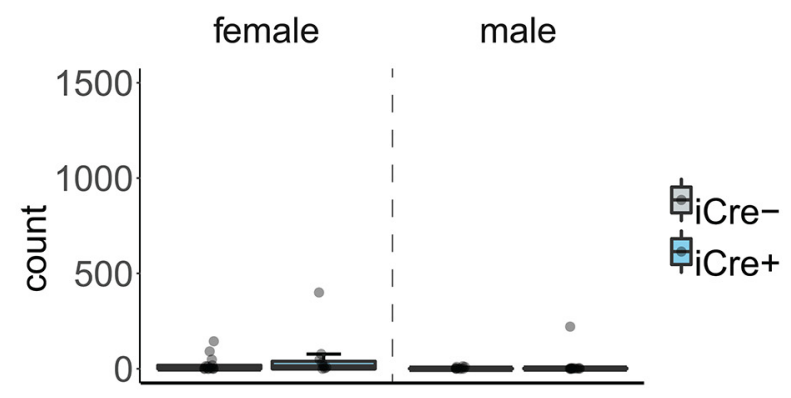

D

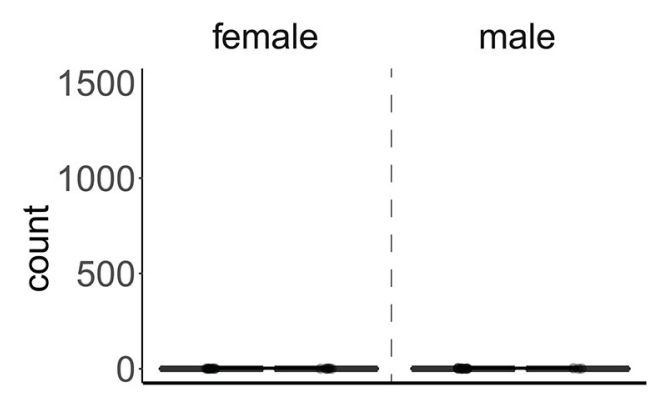

F

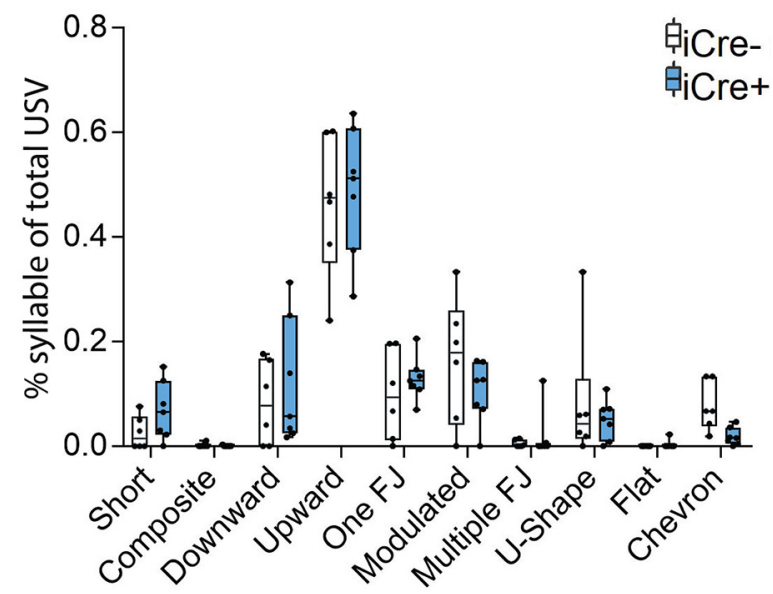

Figure 4. BNST AVP cell ablations in iCre+ animals did not alter USVs. Boxplot and individual data points of USV in presence of a male or female or their urine within the three-chamber apparatus. $\boldsymbol{A}, \boldsymbol{B}$, iCre- (males: $n=13$, females: $n=13$ ) and iCre+ mice (males: $n=11$, females: $n=8$ ) did not differ by genotype in USV production. $\boldsymbol{A}$, Male subjects: $p=1.0$ (female stimulus), $p=0.33$ (male stimulus). $\boldsymbol{B}$, Female subjects: $p=0.18$ (female stimulus), $p=0.16$ (male stimulus). $\boldsymbol{C}, \boldsymbol{D}$, USV with either female urine or male urine present. iCre- and iCre+ subjects did not differ in USVs to female or male urine. $\boldsymbol{C}$, Male subjects: $p=0.77$ (female stimulus), $p=$ 0.5 (male stimulus). $\boldsymbol{D}$, Female subjects: $p=0.26$ (female stimulus), $p=0.49$ (male stimulus). $\boldsymbol{E}$, USV emitted by male mice were gammatone-transformed (200-ms window) and divided into 10 categories of calls based on spectrographic parameters. $\boldsymbol{F}$, Male USV syllable type (iCre- $n=6$; iCre $+n=7$ ). BNST-AVP ablations did not change the percentage of USV syllable types produced between genotypes. Boxplot representations as in Figure 1.

differently from iCre- littermates (males: $F_{(1,22)}=0.22, p=0.64$; females: $F_{(1,19)}=2.91, p=0.10$; Fig. $\left.2 C, D\right)$.

\section{BNST AVP cell ablations in iCre+ animals did not alter the amount or spatial distribution of activity}

Overall, mice of both genotypes traveled similar distances throughout the three-chamber apparatus (males:
$F_{(1,22)}=3.48, p=0.33$; females: $\left.F_{(1,19)}=3.47, p=0.08\right)$; this pattern did not differ when presented with female or male stimulus animals (males: $F_{(1,22)}=0.01, p=0.92$; females: $\left.F_{(1,19)}=0.01, p=0.91\right)$. There were no differences between genotypes in the amount of time mice spent in the stimulus and clean chamber zones (males: $F_{(1,22)}=0.13, p=$ 0.72; females: $F_{(1,19)}=0.04, p=0.85$; Table 2). 
A open arms closed arms

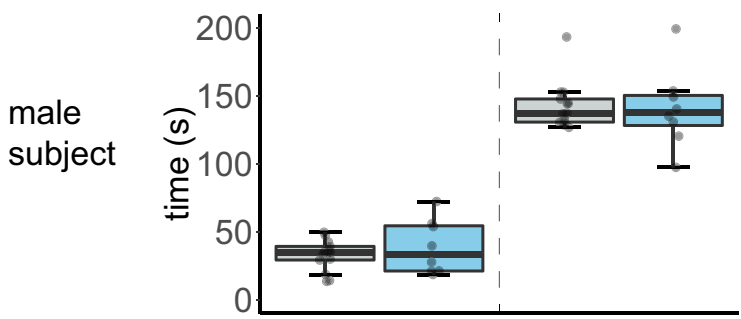

B

open arms closed arms

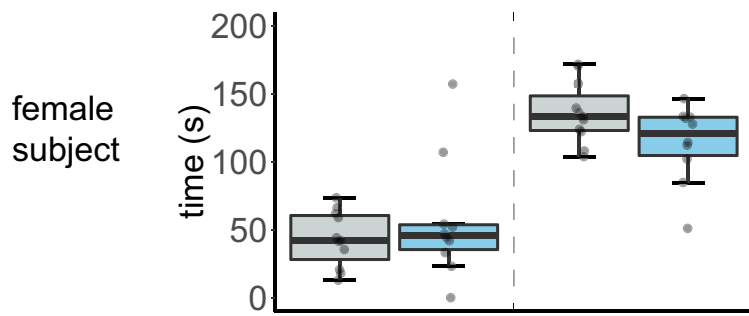

C
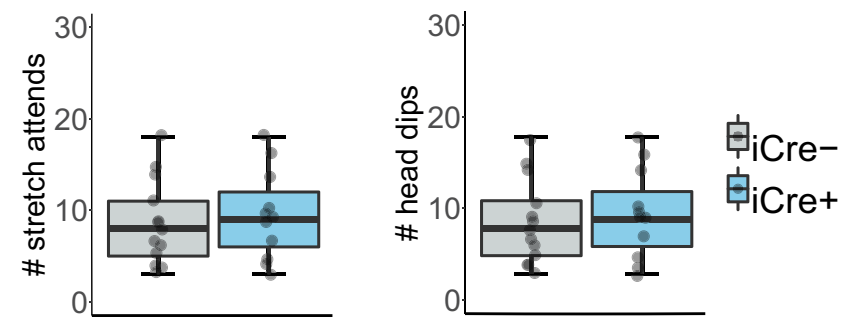

D

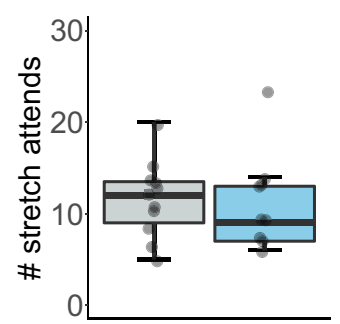

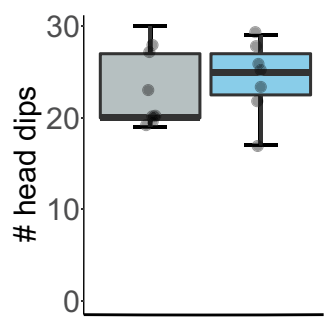

Figure 5. BNST AVP cell ablations in iCre+ animals did not influence anxiety-like behavior. Boxplot and individual data points of time spent in the open and closed arms within the EPM, number of stretch attends, and number of head dips. $\boldsymbol{A}, \boldsymbol{B}$, iCre- (males: $n=13$, females: $n=13$ ) and iCre+ mice (males: $n=11$, females: $n=8$ ) did not differ by genotype in time spent in open and closed arms. $\boldsymbol{A}$, Male subjects: $p=0.11$. $\boldsymbol{B}$, Female subjects: $p=0.59$. $\boldsymbol{C}, \boldsymbol{D}$, iCre- mice (males: $n=13$, females: $n=13$ ) and iCre+ mice (males: $n=11$, females: $n=8$ ) did not differ by genotype in number of stretch attends or head dips. $\boldsymbol{C}$, Male subjects: $p=0.16$. $\boldsymbol{D}$, Female subjects: $p=0.38$. Boxplot representations as in Figure 1 .

\section{BNST AVP cell ablated iCre+ males increased UM to females}

Male mice UM more in the presence of females than males $\left(F_{(1,22)}=52.62, p<0.00001\right.$. iCre- and iCre+ males differed in overall UM $\left(F_{(1,22)}=23.72, p=0.00007\right)$ and UM depending on the sex of stimulus $\left(F_{(1,22)}=21.02\right.$, $p=0.00015)$. Post hoc comparisons revealed that iCre+ males significantly increased UM to the female stimulus compared to iCre- littermates $\left(t_{(22)}=4.6, p=0.000112\right.$, $d=2.04$; Fig. $3 A$ ) but not to the male stimulus $\left(t_{(22)}=1.45\right.$, $p=0.16)$. iCre- and iCre+ females did not differ in UM in the presence of males $(U=32, p=0.32)$ or females $(U=$ $20, p=0.15$; Fig. 3A). Neither male nor female subjects differed in UM to urine depending on the sex of stimulus [male subjects: $F_{(1,22)}=1.16, p=0.70$; female subjects: $U$ $=52, p=0.467$ (female stimulus), $U=32, p=0.858$ (male stimulus)]. Only one male (iCre + ) pooled urine in the male condition, therefore we did not analyze pooled urine.

\section{BNST AVP cell ablations in iCre + animals did not alter USVs}

The total number of USVs emitted when iCre- and iCre + mice were placed with female (male subjects: $U=$ $64, p=1.0$; female subjects: $U=58, p=0.18$ ) or male animals did not differ by genotype (male subjects: $U=47$, $p=0.33$; female subjects: $U=52, p=0.16$; Fig. $4 A, B$ ). Mice from both genotypes also did not differ in USVs to female urine (male subjects: $U=60, p=0.77$; female subjects: $U=53, p=0.26$ ) or male urine (male subjects:
$U=52, p=0.5$; female subjects: $U=60, p=0.49$; Fig. $4 C, D)$. Additionally, BNST AVP cell ablations did not change the percentage of USV syllable types produced between male genotypes (short: $U=10, p=0.14$, composite: $U=22, p=1.0$, downward: $U=17, p=0.63$, upward: $U=17, p=0.63,1$ frequency jump: $U=15, p$ $=0.45$, modulated: $U=27, p=0.37$, multiple frequency jumps: $U=24.5, p=0.63$, u-shape: $U=19.5, p=0.83$, flat: $U=18, p=0.73$, chevron: $U=39, p=0.08$; Fig. $4 E, F)$.

\section{BNST AVP cell ablations in iCre + animals did not influence anxiety-like behavior}

All mice spent less time in the open arm than the closed arm of the EPM (male subjects: $F_{(1,22)}=51.74, p<$ 0.000001 ; female subjects: $\left.F_{(1,19)}=89.41, p<0.000001\right)$. iCre- and iCre+ mice did not differ in the time spent in either arm of the EPM (male subjects: $F_{(1,22)}=2.81, p=$ 0.11 ; female subjects: $F_{(1,19)}=1.30, p=0.59$; Fig. $\left.5 A, B\right)$. Additionally, both genotypes did not differ in frequency of stretch attend postures or head dips (male subjects: $F_{(1,22)}$ $=3.90, p=0.16$; female subjects: $F_{(1,19)}=0.80, p=0.38$; Fig. $5 C, D)$.

\section{BNST AVP cell ablations in iCre+ animals did not alter male copulatory behavior but did reduce mounting of females}

iCre+ and iCre- males mounted females with similar latencies and did not differ in the percentage of subjects 
A

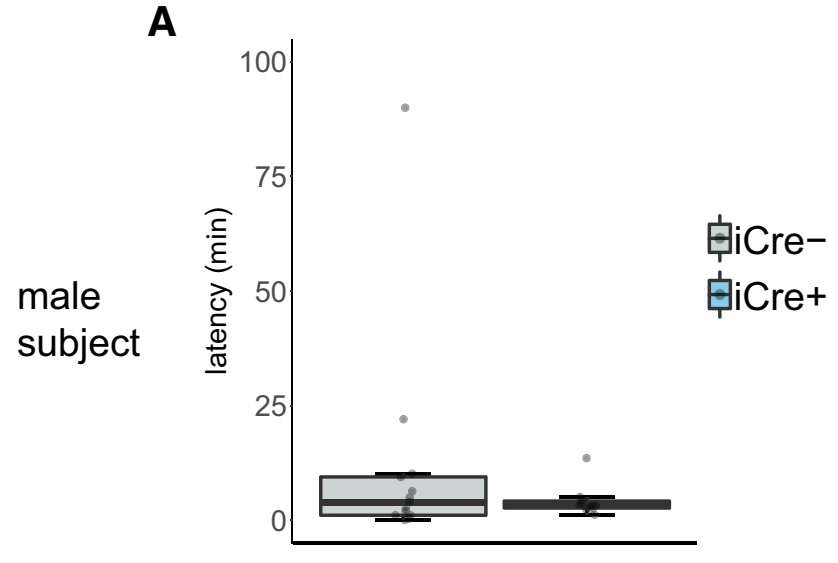

B

female
subject

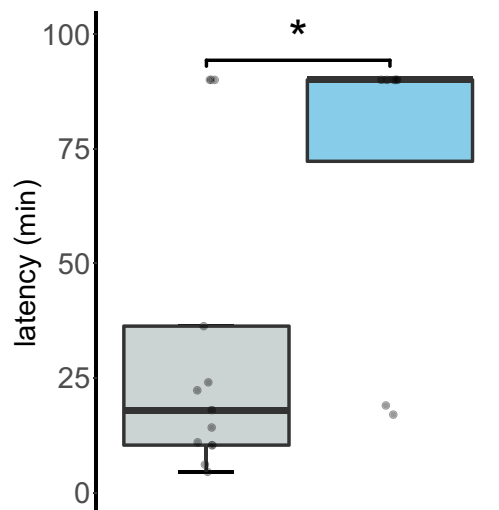

C

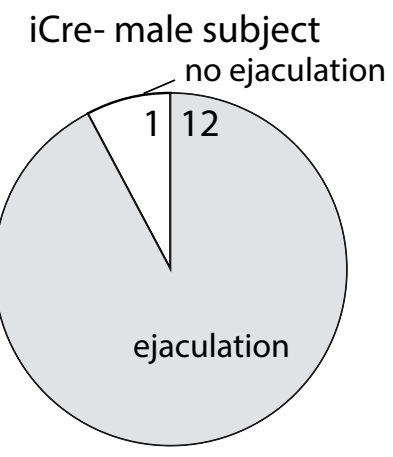

iCre+ male subject

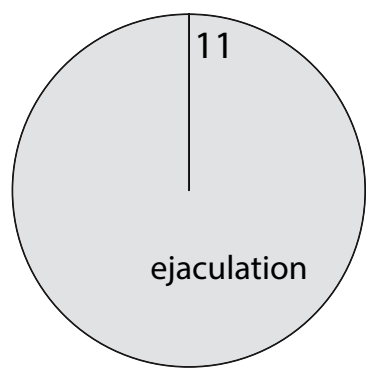

D
iCre+ female subject
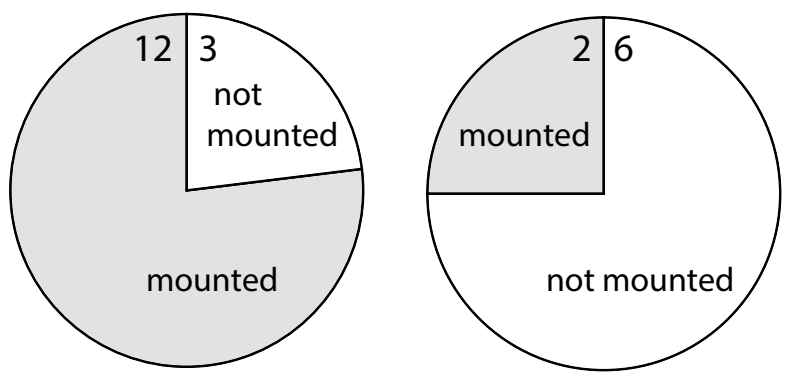

Figure 6. BNST AVP cell ablations in iCre+ animals did not alter male copulatory behavior but did reduce mounting of females. Boxplot and individual data points of male subject's latency to mount a female $(\boldsymbol{A})$ or female subject's latency to be mounted $(\boldsymbol{B})$. Pie chart summarizing proportion of male subjects that ejaculated $(\boldsymbol{C})$ or the proportion of female subjects mounted by a male $(\boldsymbol{D})$ with number of subjects in each category indicated. $\boldsymbol{A}, \boldsymbol{C}$, iCre- $(n=13)$ and iCre $+(n=11)$ male mice did not differ by genotype in their latency to mount females or in the percentage of subjects ejaculating. $\boldsymbol{B}, \boldsymbol{D}$, iCre+ $(n=8)$ female mice were mounted at longer latencies $(p=0.03)$ and proportionally less $(p<0.000001)$ than iCre- $(n=13)$ females; $*$ indicates significant effect of genotype, $p=0.03$. Boxplot representations as in Figure 1 .

mounting and/or ejaculating $\left(t_{(22)}=1.04, p=0.31\right.$; Fig. $6 A, C)$. However, it took longer for males to mount iCre+ females $(U=22, p=0.03)$ and fewer iCre + females were mounted overall as compared to iCre-females $\left(\chi^{2}(2), p<\right.$ $0.000001)$. However, female iCre+ mice did not reject stimulus males more frequently than did iCre- females $\left(t_{(19)}=0.52, p=0.61\right)$. One iCre + female was removed during the sex behavior test and sex behavior analysis because the stimulus male attacked the female.

\section{BNST AVP cell ablation did not alter territorial aggression}

The proportion of male subjects that attacked the subordinate intruder in their home cage did not differ between genotypes $\left(\chi^{2}(2), p=0.85\right)$ nor did they differ in attack latency $(U=60, p=0.955$; Fig. $7 A, B)$. Female subjects did not attack female intruders.

\section{BNST AVP cell ablations did not change the ability to discriminate between social odors}

Males and females of both genotypes were able to discriminate between male and female urine odors [males: $t_{(10)}=7.936, p=0.00001$ (iCre-), $t_{(4)}=8.313, p=0.001$ (iCre+); females: $t_{(4)}=7.071, p=0.002$ (iCre-), $t_{(6)}=$ $5.211, p=0.002$ (iCre+)] and could distinguish between non-social and social odors [males: $t_{(10)}=11.41, p<$ 0.00001 (iCre-), $t_{(4)}=6.675, p=0.003$ (iCre+); females: $t_{(4)}=6.197, p=0.003$ (iCre-), $t_{(6)}=7.454, p=0.0003$ (iCre+)]. However, subjects' ability to discriminate between non-social odors was not robust (Fig. $8 A, B$ ). Although both iCre+ and iCre- males discriminated between water and almond odor, females did not, and no subjects discriminated between the two non-social odors (Table 1).

\section{Discussion}

We found that deletion of the sexually dimorphic AVP cell group in the BNST significantly affected social behavior in males, reducing social investigation of other males and increasing UM in the presence of a female. In females, which have significantly fewer AVP BNST cells, similar deletions minimally affected social behavior and communication. This is the first time that direct alteration of a male-biased, sexually-dimorphic population of neu- 
A

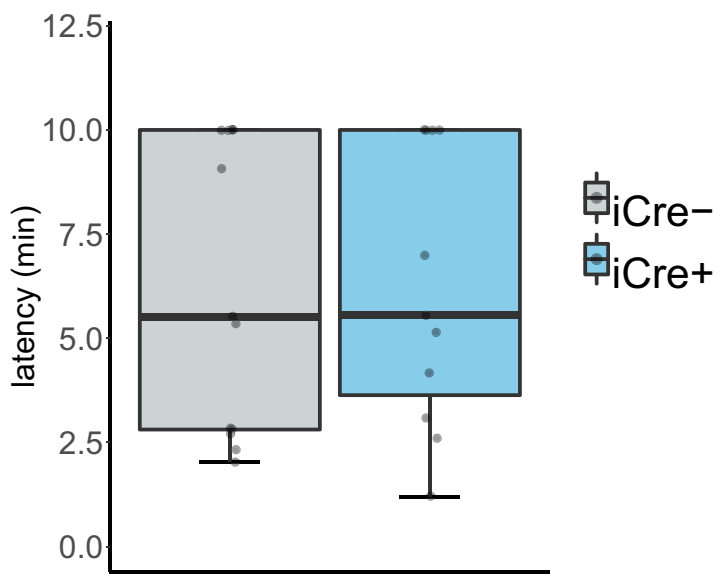

B

iCre- male subject

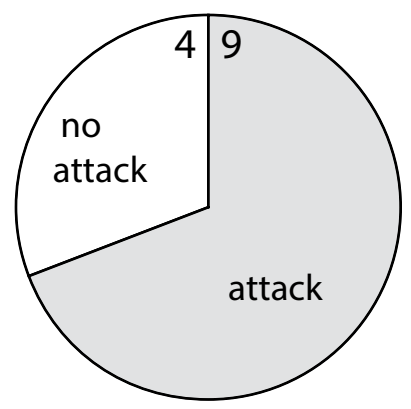

iCre+ male subject

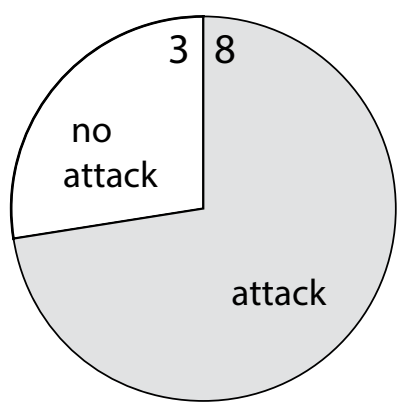

Figure 7. BNST AVP cell ablation did not alter territorial aggression. $\boldsymbol{A}$, Boxplot and individual data points of male subject's latency to attack a subordinate intruder male. iCre- $(n=13)$ and iCre $+(n=11)$ male mice did not differ by genotype in latency to attack the intruder $(p=0.955)$. $\boldsymbol{B}$, Pie chart summarizing proportion of male subjects that attacked the subordinate intruder in their home cage with number of subjects in each category indicated. Subjects did not differ between genotypes $(p=0.85)$. Boxplot representations as in Figure 1.

ropeptidergic cells has caused a sex difference in mammalian social responses. While several studies have directly tested the social function of sexually-dimorphic cell populations (Yang et al., 2013; Scott et al., 2015; Unger et al., 2015; Wei et al., 2018), only one has found a strong sex difference in social behavior tied to an anatomic sexual dimorphism, in this case a female-biased one (Scott et al., 2015). Our results indicate that sex differences in AVP cells in the BNST contributes to sexually dimorphic components of social communication.

Our experiments do not allow us to conclude that removal of AVP production in the BNST, by and of itself, caused the behavioral effects observed in this study. Lesioning AVP cells also removed all other neuroactive substances co-expressed by these cells, for example, galanin (Miller et al., 1993), which also has been implicated in control of social behavior (Wu et al., 2014). Consequently, our behavioral results may be due to depletion of AVP, or of co-transmitters from BNST projections, or both. Our finding of reduced male-male investigation following BNST AVP cell deletion, however, is strikingly similar to the effects of RNA interference for the homologous peptide arginine vasotocin (AVT) in the BNST of territorial finches (Kelly and Goodson, 2013b) and suggests that this effect is mainly due to a reduction of AVP signal from the BNST.

Our cell deletion approach is, by design, permanent, and so behavioral effects may reflect molecular, cellular, and anatomic adjustments or compensations to chronic depletion of AVP cells in the BNST. Indeed, long-term pharmacological reduction of $\mathrm{V} 1 \mathrm{a}$ receptor activity in the LS, a key target of AVP cells in the BNST (De Vries and Panzica, 2006), produces different changes in behavior than acute receptor blockade (Liebsch et al., 1996; Everts and Koolhaas, 1999). A lack of an effect on a behavior, therefore, does not exclude involvement of these cells in that behavior. Nevertheless, our findings of male-specific alterations in social interactions and communication fol- lowing deletion of AVP cells in the BNST strongly indicate that in males these cells are critical for these functions.

One of the strongest effects of deletion of AVP cells in the BNST was the reduction of same-sex social investigation, which we found in males but not in females. Importantly, this reduction was not due to a lack of general social interest, as investigation of females was unchanged. It was not due to changes in general chemosensory function or motor behavior either, as odor habituation or discrimination of non-social odors and detection of social odors (male or female urine) was unaffected and measures of general activity were also not changed. This reduction can also not be explained by a general increase in anxiety-like behaviors, because the lesions did not affect behavior in the anxiogenic EPM. Instead, it suggests that one function of AVP cells in the BNST is to generate male-typical approach, investigation, and assessment of potential territorial competitors (Oldfield et al., 2015), which is consistent with the observation that knocking down AVT mRNA in the BNST of territorial birds reduces social contact with other males (Kelly and Goodson, 2013b), and that overexpression of $\mathrm{V} 1 \mathrm{a}$ receptors (Landgraf et al., 2003) or AVP injections (Koolhaas et al., 1991) in the LS, a key target for AVP projections from the BNST (De Vries and Panzica, 2006), increases active male-male interactions and aggressive behavior in rats. Indeed, retrodialysis of V1aR antagonist into the LS of male rats blocks further territorial aggression during repeated resident-intruder tests (Veenema et al., 2010). Our finding that deleting AVP cells in the BNST reduced investigation of potential competitors is consistent with these findings. Our failure to see a change in aggressive behavior is not. One explanation for this apparent discrepancy is that AVP from other sources contribute to stimulating effects on aggressive behavior in areas such as the LS. For example, AVP cells in the MeA show similar dimorphisms as BNST cells and project to overlapping areas (De Vries and Panzica, 2006). Lesioning both cell 
A

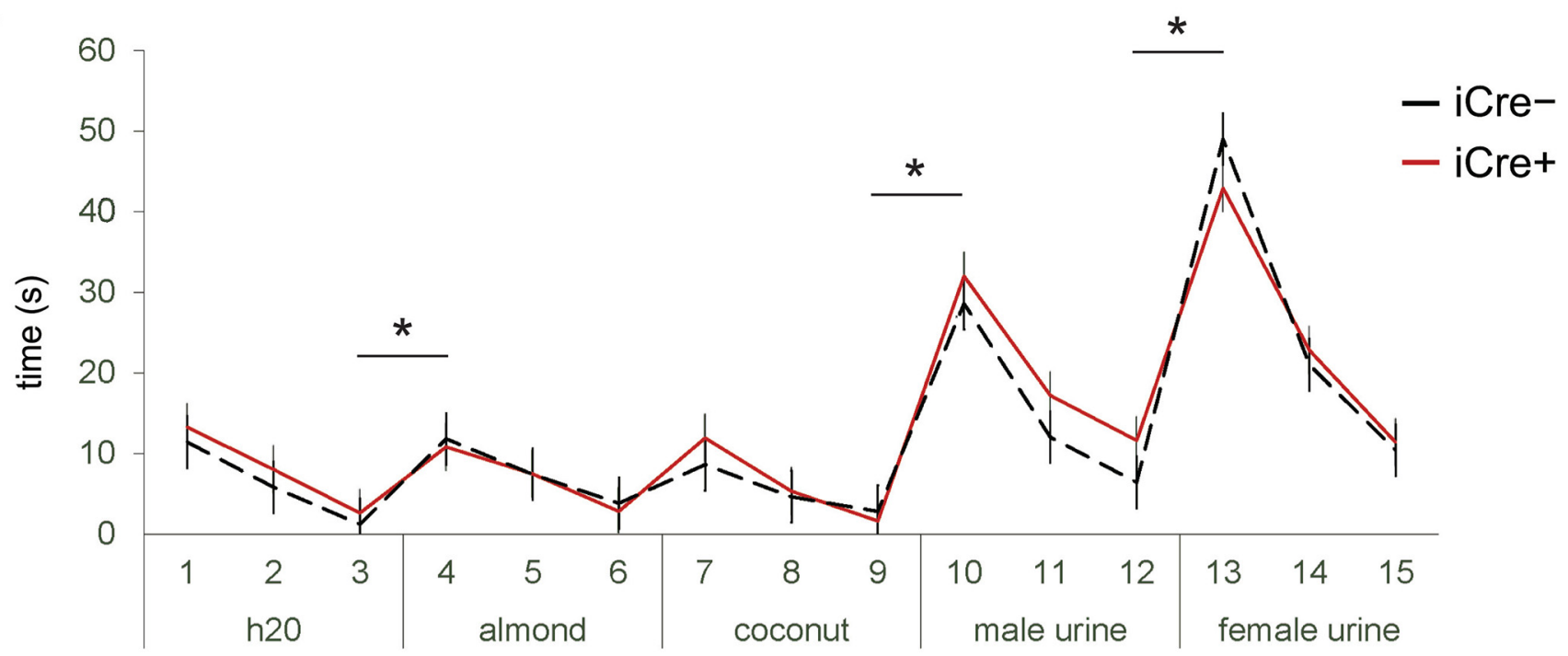

B

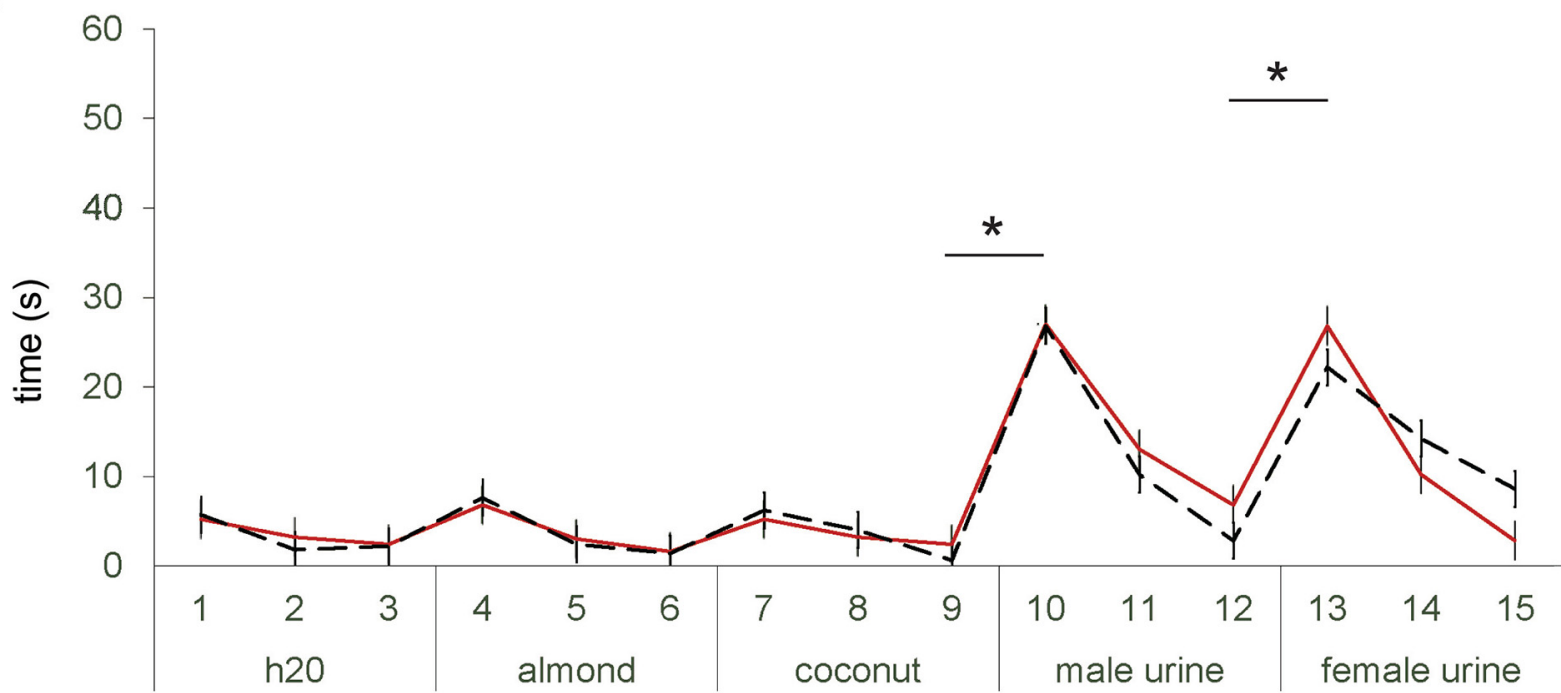

Figure 8. BNST AVP cell ablations did not change the ability to discriminate between social odors. Time spent investigating water, almond or coconut extract, male urine, or female urine. $\boldsymbol{A}$, Males and $\boldsymbol{B}$, females of both genotypes were able to discriminate between male and female urine odors $[\boldsymbol{A}$, males: $p=0.00001$ (iCre-), $p=0.001$ (iCre+); $\boldsymbol{B}$, females: $p=0.002$ (iCre-), $p=0.002$ (iCre + )] and could distinguish between non-social and social odors [males: $p<0.00001$ (iCre-), $p=0.003$ (iCre+); $p=0.003$ (iCre-), $p=$ 0.0003 (iCre+)]. However, subjects' ability to discriminate between non-social odors was not robust. Although both iCre+ and iCremales discriminated between water and almond odor, females did not, and no subjects discriminated between the two non-social odors. Data are expressed as mean $( \pm)$ SEM; trial numbers are given on the $\mathrm{x}$-axis; $*$ indicates significant difference (all $p<0.005)$ between investigation of odors, irrespective of genotype.

groups may be necessary to identify all behaviors in which these sexually dimorphic cell groups are critically involved. Nevertheless, AVP cells in the BNST appear to be required for the proactive investigation of credible social threats rather than for offensive aggression per se.

Ablation of AVP cells in the BNST of male, but not female, mice strongly increased UM toward females, suggesting that these cells normally suppress male scent marking toward females. This increase in UM is not due to excessive eliminative urination because it was not observed toward male stimuli nor was it manifested as an increase in pooled urine. It is possible that this increase is simply due to increased proximity and interest in females.
However, males with deletions of AVP cells in the BNST did not differ from control animals in time spent investigating female stimuli, making this explanation less likely. Although UM strongly depends on chemosensory processing (Maruniak et al., 1986; Labov and Wysocki, 1989), the increase in UM by lesioned males was not driven primarily by female urine cues because marking to female urine was not increased, suggesting that other cues, chemosensory as well as non-chemosensory, may drive this increase in scent marking. Given the metabolic costs of urination (Gosling et al., 2000) and the increased risks associated with attraction of aggressive competitors and predators toward urine marks (Desjardins et al., 1973; 
Roberts et al., 2001), UM should be strongly regulated so that signaling occurs in only specific social contexts. The present results indicate that the BNST-AVP cells may be a key part of the neural system that adaptively regulates this critical signaling behavior.

Although AVP/AVT has been implicated in the production of vocalizations across taxa (Goodson and Bass, 2001), deleting the AVP cells in the BNST did not significantly alter the production of USVs in a reproductive context. This is consistent with the few studies examining male courtship vocalizations (in birds) that report no effect of central infusions of AVT or V1a antagonists on femaledirected singing (Goodson and Adkins-Regan, 1999; Goodson and Evans, 2004) or got mixed results from antisense knock-down of BNST-AVP, with one study finding no effect (Kelly et al., 2011) and another observing decreased singing (Kelly and Goodson, 2013b). Most other studies supporting a role for AVP/AVT in vocalizations have not identified the relevant neuroanatomical source of the peptide or its locus of action (Wilczynski et al., 2017) or tended to focus on stress-related or aggressive vocalizations across development (Winslow and Insel, 1993; Bleickardt et al., 2009; lijima et al., 2014; Lukas and Wöhr, 2015; Paul et al., 2016; Freeman et al., 2018).

Our study also points to a limited, sexually dimorphic role of BNST AVP cells in reproductive behavior. Removal of these cells in males did not alter copulatory behavior, which is consistent with the absence of copulatory deficits in whole-animal knock-outs of $\mathrm{V} 1 \mathrm{a}$ or $\mathrm{V} 1 \mathrm{~b}$ receptors (Wersinger et al., 2004, 2007). However, unexpectedly, ablating these cells in females delayed, and reduced the number of times they were mounted by males. This effect may represent reduced attractiveness of the female or an increased rejection of the male. The latter possibility seems less likely, as we did not detect any change in male investigation toward lesioned females, nor did such females reject males more frequently. It is possible that these females show decreases in cryptic proceptive and/or receptive behaviors. Although AVP has been implicated in female rat sexual behavior, the pattern of prior results is opposite to our findings: in rats, AVP reduced, whereas $\mathrm{V} 1 \mathrm{a}$ receptor antagonists increased, female sexual behavior in rats (Södersten et al., 1983; Pedersen and Boccia, 2006). However, as in these studies peptides were injected into the lateral ventricle, it is unclear with what AVP system they interacted.

Although central AVP has been repeatedly implicated in the generation of anxiety states (Ebner et al., 2002; Bielsky et al., 2004; Raggenbass, 2008), we did not observe changes in anxiety-like behavior of lesioned males or females in a non-social anxiogenic environment (Hogg, 1996). This is somewhat surprising because AVP in the LS, an important target of the BNST AVP cells (De Vries and Panzica, 2006), controls anxious states. For example, injections of AVP or V1aR antagonists, or V1aR knockdown within LS all support the idea that AVP is anxiogenic at this site (Landgraf et al., 1995; Liebsch et al., 1996; Beiderbeck et al., 2007). However, since large lesions of BNST have no effect on anxiety-like behavior in the EPM task either (Treit et al., 1998), it may simply mean that, as with aggressive behavior, AVP cells in the BNST are not critically involved in anxiety-like behaviors, and that AVP derived from other sources, such as the PVN or the amygdala (Rood et al., 2013), also drive AVP's anxiogenic action in the septum and elsewhere.

\section{Conclusions}

A growing body of literature indicates that vasopressin plays a sexually dimorphic role in control of social and anxiety-related behaviors. In humans, for example, intranasal vasopressin stimulates reciprocation of cooperation in males and conciliatory behavior in females, while activating brain areas implicated in reward, social bonding, arousal and memory in males, but not in females (Rilling et al., 2014). In hamsters, hypothalamic injections of vasopressin stimulate aggression in males, while reducing it in females (Terranova et al., 2016). In mice, a genetic knock-out of the vasopressin $\mathrm{V} 1 \mathrm{a}$ receptor gene reduces anxiety-related behaviors in males, but not in females (Bielsky et al., 2004, 2005). In rats, a V1a antagonist reduces social play in males while increasing them in females when injected intracerebroventricularly, but has the exact opposite effect when injected into the septum (Veenema et al., 2013). Although, these studies clearly point at a sexually dimorphic role of vasopressin and its cognate receptor in behavior, they do not identify which AVP system is involved, and the opposite effects in play behavior, depending on the area injected, suggests that more than one system may be involved. By targeting a specific AVP cell group directly, our study has identified the sexually dimorphic AVP cells in the BNST as contributing to sex differences in social behavior, and has shown the feasibility of following a similar approach in identifying the contributions of other AVP systems in the brain as well.

\section{References}

Albers HE (2012) The regulation of social recognition, social communication and aggression: vasopressin in the social behavior neural network. Horm Behav 61:283-292. CrossRef Medline

Arakawa H, Arakawa K, Blanchard DC, Blanchard RJ (2008a) A new test paradigm for social recognition evidenced by urinary scent marking behavior in C57BL/6J mice. Behav Brain Res 190:97-104. CrossRef Medline

Arakawa H, Blanchard DC, Arakawa K, Dunlap C, Blanchard RJ (2008b) Scent marking behavior as an odorant communication in mice. Neurosci Biobehav Rev 32:1236-1248. CrossRef Medline

Bakker J, Honda S-I, Harada N, Balthazart J (2002) The aromatase knock-out mouse provides new evidence that estradiol is required during development in the female for the expression of sociosexual behaviors in adulthood. J Neurosci 22:9104-9112. CrossRef Medline

Barkley MS, Goldman BD (1977) The effects of castration and Silastic implants of testosterone on intermale aggression in the mouse. Horm Behav 9:32-48. CrossRef Medline

Baum MJ, Keverne EB (2002) Sex difference in attraction thresholds for volatile odors from male and estrous female mouse urine. Horm Behav 41:213-219. CrossRef Medline

Beeman EA (1947) The relation of the interval between castration and first encounter to the aggressive behavior of mice. Anat Rec 99:570. Medline

Beiderbeck DI, Neumann ID, Veenema AH (2007) Differences in intermale aggression are accompanied by opposite vasopressin 
release patterns within the septum in rats bred for low and high anxiety. Eur J Neurosci 26:3597-3605. CrossRef Medline

Bielsky IF, Hu SB, Szegda KL, Westphal H, Young LJ (2004) Profound impairment in social recognition and reduction in anxietylike behavior in vasopressin $\mathrm{V} 1 \mathrm{a}$ receptor knockout mice. Neuropsychopharmacology 29:483-493. CrossRef Medline

Bielsky IF, Hu SB, Young LJ (2005) Sexual dimorphism in the vasopressin system: lack of an altered behavioral phenotype in female V1a receptor knockout mice. Behav Brain Res 164:132-136. CrossRef Medline

Bishop MJ, Chevins PF (1987) Urine odours and marking patterns in territorial laboratory mice (Mus musculus). Behav Processes 15: 233-248. CrossRef Medline

Bleickardt CJ, Mullins DE, Macsweeney CP, Werner BJ, Pond AJ, Guzzi MF, Martin FDC, Varty GB, Hodgson RA (2009) Characterization of the $\mathrm{V} 1 \mathrm{a}$ antagonist, $\mathrm{JNJ}-17308616$, in rodent models of anxiety-like behavior. Psychopharmacology 202:711-718. CrossRef Medline

Bradbury JW, Vehrencamp SL (1998) Principles of animal communication, Ed 2. Sunderland, MA: Sinauer Associates, Oxford University Press.

Caligioni CS (2009) Assessing reproductive status/stages in mice. Curr Protoc Neurosci Appendix 4:Appendix 4I. CrossRef Medline

Chabout J, Sarkar A, Dunson DB, Jarvis ED (2015) Male mice song syntax depends on social contexts and influences female preferences. Front Behav Neurosci 9:76. CrossRef Medline

Cole JC, Rodgers RJ (1993) An ethological analysis of the effects of chlordiazepoxide and bretazenil (Ro 16-6028) in the murine elevated plus-maze. Behav Pharmacol 4:573-580. Medline

Compaan JC, Buijs RM, Pool CW, De Ruiter AJ, Koolhaas JM (1993) Differential lateral septal vasopressin innervation in aggressive and nonaggressive male mice. Brain Res Bull 30:1-6. CrossRef Medline

Connor JL, Winston H (1972) Genetic analysis of conditioned emotional responses in the mouse (Mus musculus L.). J Comp Physiol Psychol 81:37-44. Medline

Coquelin A (1992) Urine-marking by female mice throughout their reproductive cycle. Horm Behav 26:255-271. CrossRef Medline

Crawley JN (2007) Mouse behavioral assays relevant to the symptoms of autism. Brain Pathol 17:448-459. CrossRef Medline

Crawley JN (2012) Translational animal models of autism and neurodevelopmental disorders. Dialogues Clin Neurosci 14:293-305. Medline

Dantzer R, Koob GF, Bluthé RM, Le Moal M (1988) Septal vasopressin modulates social memory in male rats. Brain Res 457:143-147. CrossRef Medline

Darwin C (1871) The descent of man, and selection in relation to sex. Princeton, NJ: Princeton University Press.

Desjardins C, Maruniak JA, Bronson FH (1973) Social rank in house mice: differentiation revealed by ultraviolet visualization of urinary marking patterns. Science 182:939-941. CrossRef Medline

De Vries GJ (2008) Sex differences in vasopressin and oxytocin innervation of the brain. Prog Brain Res 170:17-27. CrossRef Medline

De Vries GJ, Buijs RM (1983) The origin of the vasopressinergic and oxytocinergic innervation of the rat brain with special reference to the lateral septum. Brain Res 273:307-317. CrossRef Medline

De Vries GJ, Boyle PA (1998) Double duty for sex differences in the brain. Behav Brain Res 92:205-213. CrossRef Medline

De Vries GJ, Panzica GC (2006) Sexual differentiation of central vasopressin and vasotocin systems in vertebrates: different mechanisms, similar endpoints. Neuroscience 138:947-955. CrossRef Medline

Dumais KM, Veenema AH (2016) Vasopressin and oxytocin receptor systems in the brain: sex differences and sex-specific regulation of social behavior. Front Neuroendocrinol 40:1-23. CrossRef Medline

Ebner K, Wotjak CT, Landgraf R, Engelmann M (2000) A single social defeat experience selectively stimulates the release of oxytocin, but not vasopressin, within the septal brain area of male rats. Brain Res 872:87-92. CrossRef Medline
Ebner K, Wotjak CT, Landgraf R, Engelmann M (2002) Forced swimming triggers vasopressin release within the amygdala to modulate stress-coping strategies in rats. Eur $\mathrm{J}$ Neurosci 15:384-388. CrossRef Medline

Everts HG, Koolhaas JM (1999) Differential modulation of lateral septal vasopressin receptor blockade in spatial learning, social recognition, and anxiety-related behaviors in rats. Behav Brain Res 99:7-16. CrossRef Medline

Everts HG, De Ruiter AJ, Koolhaas JM (1997) Differential lateral septal vasopressin in wild-type rats: correlation with aggression. Horm Behav 31:136-144. CrossRef Medline

Freeman AR, Hare JF, Anderson WG, Caldwell HK (2018) Effects of arginine vasopressin on Richardson's ground squirrel social and vocal behavior. Behav Neurosci 132:34-50. CrossRef Medline

Gheusi G, Bluth R-M, Goodall G, Dantzer R (1994) Social and individual recognition in rodents: methodological aspects and neurobiological bases. Behav Processes 33:59-87. CrossRef Medline

Goodson JL, Adkins-Regan E (1999) Effect of intraseptal vasotocin and vasoactive intestinal polypeptide infusions on courtship song and aggression in the male zebra finch (Taeniopygia guttata). J Neuroendocrinol 11:19-25. Medline

Goodson JL, Bass AH (2001) Social behavior functions and related anatomical characteristics of vasotocin/vasopressin systems in vertebrates. Brain Res Brain Res Rev 35:246-265. Medline

Goodson JL, Evans AK (2004) Neural responses to territorial challenge and nonsocial stress in male song sparrows: segregation, integration, and modulation by a vasopressin V1 antagonist. Horm Behav 46:371-381. CrossRef Medline

Goodson JL, Kabelik D, Schrock SE (2009) Dynamic neuromodulation of aggression by vasotocin: influence of social context and social phenotype in territorial songbirds. Biol Lett 5:554-556. CrossRef Medline

Gosling LM, Roberts SC, Thornton EA, Andrew MJ (2000) Life history costs of olfactory status signalling in mice. Behav Ecol Sociobio 48:328-332. CrossRef

Halladay AK, Bishop S, Constantino JN, Daniels AM, Koenig K, Palmer K, Messinger D, Pelphrey K, Sanders SJ, Singer AT, Taylor JL, Szatmari P (2015) Sex and gender differences in autism spectrum disorder: summarizing evidence gaps and identifying emerging areas of priority. Mol Autism 6:36. CrossRef Medline

Hanson JL, Hurley LM (2012) Female presence and estrous state influence mouse ultrasonic courtship vocalizations. PLoS One 7:e40782. CrossRef Medline

Hogg S (1996) A review of the validity and variability of the elevated plus-maze as an animal model of anxiety. Pharmacol Biochem Behav 54:21-30. CrossRef Medline

Ho JM, Murray JH, Demas GE, Goodson JL (2010) Vasopressin cell groups exhibit strongly divergent responses to copulation and male-male interactions in mice. Horm Behav 58:368-377. CrossRef Medline

lijima M, Yoshimizu T, Shimazaki T, Tokugawa K, Fukumoto K, Kurosu S, Kuwada T, Sekiguchi Y, Chaki S (2014) Antidepressant and anxiolytic profiles of newly synthesized arginine vasopressin V1B receptor antagonists: TASP0233278 and TASP0390325. Br J Pharmacol 171:3511-3525. CrossRef Medline

Insel TR (2010) The challenge of translation in social neuroscience: a review of oxytocin, vasopressin, and affiliative behavior. Neuron 65:768-779. CrossRef Medline

Kelly AM, Goodson JL (2013a) Functional significance of a phylogenetically widespread sexual dimorphism in vasotocin/vasopressin production. Horm Behav 64:840-846. CrossRef Medline

Kelly AM, Goodson JL (2013b) Behavioral relevance of speciesspecific vasotocin anatomy in gregarious finches. Front Neurosci 7:242. CrossRef Medline

Kelly AM, Kingsbury MA, Hoffbuhr K, Schrock SE, Waxman B, Kabelik D, Thompson RR, Goodson JL (2011) Vasotocin neurons and septal V1a-like receptors potently modulate songbird flocking and responses to novelty. Horm Behav 60:12-21. CrossRef Medline 
Koolhaas JM, Moor E, Hiemstra Y, Bohus B (1991) The testosteronedependent vasopressinergic neurons in the medial amygdala and lateral septum: Involvement in social behaviour of male rats. In Vasopressin, (Jard S, Jamison R, eds), pp 213-219. Paris/London: INSERM/John Libbey Eurotext Ltd.

Koolhaas JM, Coppens CM, de Boer SF, Buwalda B, Meerlo P, Timmermans PJ (2013) The resident-intruder paradigm: a standardized test for aggression, violence and social stress. J Vis Exp (77):e4367. CrossRef Medline

Labov JB, Wysocki CJ (1989) Vomeronasal organ and social factors affect urine marking by male mice. Physiol Behav 45:443-447. CrossRef Medline

Landgraf R, Gerstberger R, Montkowski A, Probst JC, Wotjak CT, Holsboer F, Engelmann M (1995) V1 vasopressin receptor antisense oligodeoxynucleotide into septum reduces vasopressin binding, social discrimination abilities, and anxiety-related behavior in rats. J Neurosci 15:4250-4258. CrossRef Medline

Landgraf R, Frank E, Aldag JM, Neumann ID, Sharer CA, Ren X, Terwilliger EF, Niwa M, Wigger A, Young LJ (2003) Viral vectormediated gene transfer of the vole $\mathrm{V} 1 \mathrm{a}$ vasopressin receptor in the rat septum: improved social discrimination and active social behaviour. Eur J Neurosci 18:403-411. CrossRef Medline

Lehmann ML, Geddes CE, Lee JL, Herkenham M (2013) Urine scent marking (USM): a novel test for depressive-like behavior and a predictor of stress resiliency in mice. PLoS One 8:e69822. CrossRef Medline

Liebsch G, Wotjak CT, Landgraf R, Engelmann M (1996) Septal vasopressin modulates anxiety-related behaviour in rats. Neurosci Lett 217:101-104. CrossRef Medline

Lim MM, Young LJ (2004) Vasopressin-dependent neural circuits underlying pair bond formation in the monogamous prairie vole. Neuroscience 125:35-45. CrossRef Medline

Lim MM, Hammock EAD, Young LJ (2004) The role of vasopressin in the genetic and neural regulation of monogamy. J Neuroendocrinol 16:325-332. CrossRef Medline

Lister RG (1987) The use of a plus-maze to measure anxiety in the mouse. Psychopharmacology 92:180-185. Medline

Liu Y, Curtis JT, Wang Z (2001) Vasopressin in the lateral septum regulates pair bond formation in male prairie voles (Microtus ochrogaster). Behav Neurosci 115:910-919. CrossRef Medline

Ludwig M, Stern J (2015) Multiple signaling modalities mediated by dendritic exocytosis of oxytocin and vasopressin. Philos Trans R Soc Lond B Biol Sci 370:20140182. CrossRef Medline

Lukas M, Wöhr M (2015) Endogenous vasopressin, innate anxiety, and the emission of pro-social $50-\mathrm{kHz}$ ultrasonic vocalizations during social play behavior in juvenile rats. Psychoneuroendocrinology 56:35-44. CrossRef Medline

Lumley LA, Sipos ML, Charles RC, Charles RF, Meyerhoff JL (1999) Social stress effects on territorial marking and ultrasonic vocalizations in mice. Physiol Behav 67:769-775. CrossRef Medline

Maggio JC, Whitney G (1985) Ultrasonic vocalizing by adult female mice (Mus musculus). J Comp Psychol 99:420-436. CrossRef Medline

Maruniak JA, Wysocki CJ, Taylor JA (1986) Mediation of male mouse urine marking and aggression by the vomeronasal organ. Physiol Behav 37:655-657. CrossRef Medline

Matochik JA, Sipos ML, Nyby JG, Barfield RJ (1994) Intracranial androgenic activation of male-typical behaviors in house mice: motivation versus performance. Behav Brain Res 60:141-149. CrossRef Medline

Meyer $\mathrm{H}$ (1957) The ninhydrin reaction and its analytical applications. Biochem J 67:333-340. CrossRef Medline

Mieda M, Ono D, Hasegawa E, Okamoto H, Honma K-I, Honma S, Sakurai T (2015) Cellular clocks in AVP neurons of the SCN are critical for interneuronal coupling regulating circadian behavior rhythm. Neuron 85:1103-1116. CrossRef Medline

Miller MA, Kolb PE, Raskind MA (1993) Extra-hypothalamic vasopressin neurons coexpress galanin messenger RNA as shown by double in situ hybridization histochemistry. J Comp Neurol 329: 378-384. CrossRef Medline
Moncho-Bogani J, Lanuza E, Lorente MJ, Martinez-Garcia F (2004) Attraction to male pheromones and sexual behaviour show different regulatory mechanisms in female mice. Physiol Behav 81:427434. CrossRef Medline

Morgan CW, Julien O, Unger EK, Shah NM, Wells JA (2014) Turning on caspases with genetics and small molecules. Methods Enzymol 544:179-213. CrossRef Medline

Moy SS, Nadler JJ, Young NB, Nonneman RJ, Grossman AW, Murphy DL, D'Ercole AJ, Crawley JN, Magnuson TR, Lauder JM (2009) Social approach in genetically engineered mouse lines relevant to autism. Genes Brain Behav 8:129-142. CrossRef Medline

Oldfield RG, Harris RM, Hofmann HA (2015) Integrating resource defence theory with a neural nonapeptide pathway to explain territory-based mating systems. Front Zool 12:S16. CrossRef Medline

Otero-Garcia M, Martin-Sanchez A, Fortes-Marco L, Martínez-Ricós J, Agustin-Pavón C, Lanuza E, Martínez-García F (2014) Extending the socio-sexual brain: arginine-vasopressin immunoreactive circuits in the telencephalon of mice. Brain Struct Funct 219:10551081. CrossRef Medline

Paul MJ, Peters NV, Holder MK, Kim AM, Whylings J, Terranova JI, de Vries GJ (2016) Atypical social development in vasopressindeficient brattleboro rats. eNeuro 3:ENEURO.0150-15.2016. CrossRef Medline

Paxinos G, Franklin K (2012) The mouse brain in stereotaxic coordinates, Ed 4. San Diego, CA: Academic Press.

Pedersen CA, Boccia ML (2006) Vasopressin interactions with oxytocin in the control of female sexual behavior. Neuroscience 139: 843-851. CrossRef Medline

Pitkow LJ, Sharer CA, Ren X, Insel TR, Terwilliger EF, Young LJ (2001) Facilitation of affiliation and pair-bond formation by vasopressin receptor gene transfer into the ventral forebrain of a monogamous vole. J Neurosci 21:7392-7396. CrossRef Medline

R Core Team (2013). R: A language and environment for statistical computing. R Foundation for Statistical Computing, Vienna, Austria.

Raggenbass M (2008) Overview of cellular electrophysiological actions of vasopressin. Eur J Pharmacol 583:243-254. CrossRef Medline

Rilling JK, Demarco AC, Hackett PD, Chen X, Gautam P, Stair S, Haroon E, Thompson R, Ditzen B, Patel R, Pagnoni G (2014) Sex differences in the neural and behavioral response to intranasal oxytocin and vasopressin during human social interaction. Psychoneuroendocrinology 39:237-248. CrossRef Medline

Roberts SC, Gosling LM, Thornton EA, McClung J (2001) Scentmarking by male mice under the risk of predation. Behav Ecol 12:698-705. CrossRef

Rood BD, De Vries GJ (2011) Vasopressin innervation of the mouse (Mus musculus) brain and spinal cord. J Comp Neurol 519:24342474. CrossRef Medline

Rood BD, Stott RT, You S, Smith CJW, Woodbury ME, De Vries GJ (2013) Site of origin of and sex differences in the vasopressin innervation of the mouse (Mus musculus) brain. J Comp Neurol 521:2321-2358. CrossRef Medline

Roullet FI, Wöhr M, Crawley JN (2011) Female urine-induced male mice ultrasonic vocalizations, but not scent-marking, is modulated by social experience. Behav Brain Res 216:19-28. CrossRef Medline

Schultz RT (2005) Developmental deficits in social perception in autism: the role of the amygdala and fusiform face area. Int J Dev Neurosci 23:125-141. CrossRef Medline

Scott N, Prigge M, Yizhar O, Kimchi T (2015) A sexually dimorphic hypothalamic circuit controls maternal care and oxytocin secretion. Nature 525:519-522. CrossRef Medline

Shimshek DR, Kim J, Hübner MR, Spergel DJ, Buchholz F, Casanova E, Stewart AF, Seeburg PH, Sprengel R (2002) Codon-improved Cre recombinase (iCre) expression in the mouse. Genesis 32:1926. CrossRef Medline 
Södersten P, Henning M, Melin P, Ludin S (1983) Vasopressin alters female sexual behaviour by acting on the brain independently of alterations in blood pressure. Nature 301:608-610. CrossRef Medline

Ström JO, Theodorsson A, Ingberg E, Isaksson IM, Theodorsson E (2012) Ovariectomy and $17 \beta$-estradiol replacement in rats and mice: a visual demonstration. J Vis Exp. Advance online publication. Retrieved June 12, 2012. doi:10.3791/4013

Terranova JI, Song Z, Larkin TE 2nd, Hardcastle N, Norvelle A, Riaz A, Albers HE (2016) Serotonin and arginine-vasopressin mediate sex differences in the regulation of dominance and aggression by the social brain. Proc Natl Acad Sci USA 113:13233-13238. CrossRef Medline

Treit D, Aujla H, Menard J (1998) Does the bed nucleus of the stria terminalis mediate fear behaviors? Behav Neurosci 112:379-386. CrossRef Medline

Unger EK, Burke KJ Jr, Yang CF, Bender KJ, Fuller PM, Shah NM (2015) Medial amygdalar aromatase neurons regulate aggression in both sexes. Cell Rep 10:453-462. CrossRef Medline

van Leeuwen FW, Caffe AR, De Vries GJ (1985) Vasopressin cells in the bed nucleus of the stria terminalis of the rat: sex differences and the influence of androgens. Brain Res 325:391-394. CrossRef Medline

Van Loo PL, Mol JA, Koolhaas JM, Van Zutphen BF, Baumans V (2001) Modulation of aggression in male mice: influence of group size and cage size. Physiol Behav 72:675-683. CrossRef Medline

Van Segbroeck M, Knoll AT, Levitt P, Narayanan S (2017) MUPETMouse Ultrasonic Profile ExTraction: A Signal Processing Tool for Rapid and Unsupervised Analysis of Ultrasonic Vocalizations. Neuron 94:465-485.e5. CrossRef Medline

Veenema AH, Beiderbeck DI, Lukas M, Neumann ID (2010) Distinct correlations of vasopressin release within the lateral septum and the bed nucleus of the stria terminalis with the display of intermale aggression. Horm Behav 58:273-281. CrossRef Medline

Veenema AH, Bredewold R, De Vries GJ (2012) Vasopressin regulates social recognition in juvenile and adult rats of both sexes, but in sex- and age-specific ways. Horm Behav 61:50-56. CrossRef Medline

Veenema AH, Bredewold R, De Vries GJ (2013) Sex-specific modulation of juvenile social play by vasopressin. Psychoneuroendocrinology 38:2554-2561. CrossRef Medline
Veyrac A, Wang G, Baum MJ, Bakker J (2011) The main and accessory olfactory systems of female mice are activated differentially by dominant versus subordinate male urinary odors. Brain Res 1402:20-29. CrossRef Medline

Wang Z, Smith W, Major DE, De Vries GJ (1994) Sex and species differences in the effects of cohabitation on vasopressin messenger RNA expression in the bed nucleus of the stria terminalis in prairie voles (Microtus ochrogaster) and meadow voles (Microtus pennsy/vanicus). Brain Res 650:212-218. CrossRef Medline

Wei YC, Wang SR, Jiao ZL, Zhang W, Lin JK, Li XY, Li SS, Zhang X, $\mathrm{Xu} \mathrm{XH} \mathrm{(2018)} \mathrm{Medial} \mathrm{preoptic} \mathrm{area} \mathrm{in} \mathrm{mice} \mathrm{is} \mathrm{capable} \mathrm{of} \mathrm{mediating}$ sexually dimorphic behaviors regardless of gender. Nat Commun 9:279. CrossRef Medline

Wersinger SR, Kelliher KR, Zufall F, Lolait SJ, O'Carroll A-M, Young W 3rd (2004) Social motivation is reduced in vasopressin $1 \mathrm{~b}$ receptor null mice despite normal performance in an olfactory discrimination task. Horm Behav 46:638-645. CrossRef Medline

Wersinger SR, Caldwell HK, Martinez L, Gold P, Hu S-B, Young WS 3rd (2007) Vasopressin 1a receptor knockout mice have a subtle olfactory deficit but normal aggression. Genes Brain Behav 6:540551. CrossRef Medline

Wilczynski W, Quispe M, Muñoz MI, Penna M (2017) Arginine vasotocin, the social neuropeptide of amphibians and reptiles. Front Endocrinol 8:186. CrossRef Medline

Winslow JT, Insel TR (1993) Effects of central vasopressin administration to infant rats. Eur J Pharmacol 233:101-107. CrossRef Medline

Wöhr M (2014) Ultrasonic vocalizations in Shank mouse models for autism spectrum disorders: detailed spectrographic analyses and developmental profiles. Neurosci Biobehav Rev 43:199-212. CrossRef Medline

Wu Z, Autry AE, Bergan JF, Watabe-Uchida M, Dulac CG (2014) Galanin neurons in the medial preoptic area govern parental behaviour. Nature 509:325-330. CrossRef Medline

Yang CF, Chiang MC, Gray DC, Prabhakaran M, Alvarado M, Juntti SA, Unger EK, Wells JA, Shah NM (2013) Sexually dimorphic neurons in the ventromedial hypothalamus govern mating in both sexes and aggression in males. Cell 153:896-909. CrossRef Medline 